\title{
The Central Role of Non-Structural Protein 1 (NS1) in Influenza Biology and Infection
}

\author{
Nícia Rosário-Ferreira ${ }^{1,2, * \mathbb{C}}$, António J. Preto ${ }^{2}$, Rita Melo ${ }^{2,3}{ }^{\mathbb{C}}$, Irina S. Moreira ${ }^{2,4}$ \\ and Rui M. M. Brito $1, * \mathbb{D}$ \\ 1 Coimbra Chemistry Center, Chemistry Department, Faculty of Science and Technology, \\ University of Coimbra, 3004-535 Coimbra, Portugal \\ 2 CNC - Center for Neuroscience and Cell Biology. University of Coimbra, UC Biotech Building, \\ 3060-197 Cantanhede, Portugal; antoniojosepreto@cnc.uc.pt (A.J.P.); ritamelo@ctn.tecnico.ulisboa.pt (R.M.); \\ irina.moreira@cnc.uc.pt (I.S.M.) \\ 3 Centro de Ciências e Tecnologias Nucleares and Departamento de Engenharia e Ciências Nucleares, \\ Instituto Superior Técnico, Universidade de Lisboa, 2695-066 Bobadela LRS, Portugal \\ 4 Department of Life Sciences, University of Coimbra, 3000-456 Coimbra, Portugal \\ * Correspondence: nicia.ferreira@student.uc.pt (N.R.-F.); brito@ci.uc.pt (R.M.M.B.)
}

Received: 23 November 2019; Accepted: 24 January 2020; Published: 22 February 2020

\begin{abstract}
Influenza (flu) is a contagious viral disease, which targets the human respiratory tract and spreads throughout the world each year. Every year, influenza infects around $10 \%$ of the world population and between 290,000 and 650,000 people die from it according to the World Health Organization (WHO). Influenza viruses belong to the Orthomyxoviridae family and have a negative sense eight-segment single-stranded RNA genome that encodes 11 different proteins. The only control over influenza seasonal epidemic outbreaks around the world are vaccines, annually updated according to viral strains in circulation, but, because of high rates of mutation and recurrent genetic assortment, new viral strains of influenza are constantly emerging, increasing the likelihood of pandemics. Vaccination effectiveness is limited, calling for new preventive and therapeutic approaches and a better understanding of the virus-host interactions. In particular, grasping the role of influenza non-structural protein 1 (NS1) and related known interactions in the host cell is pivotal to better understand the mechanisms of virus infection and replication, and thus propose more effective antiviral approaches. In this review, we assess the structure of NS1, its dynamics, and multiple functions and interactions, to highlight the central role of this protein in viral biology and its potential use as an effective therapeutic target to tackle seasonal and pandemic influenza.
\end{abstract}

Keywords: protein structure; structural bioinformatics; molecular modeling; protein-protein interactions; PPIs; influenza virus; NS1

\section{Introduction}

Influenza viruses can infect a vast array of animal hosts. They feature an evolutionary ability to explore genetic diversity through gene changes such as antigenic shift or antigenic drift, boosting flu's seasonal or pandemic outbreaks. Influenza infects over one billion people worldwide each year with three to five million of them affected by severe symptoms and around 290 to 650 thousand deaths each year [1,2]. Worldwide statistics show that over three million dollars are spent every year in influenza-related hospital care [3]. Thus, the worldwide annual financial impact of seasonal influenza is enormous, but pales in comparison with a pandemic outbreak of influenza which can go up to three trillion dollars [4]. For example, during the most recent worldwide outbreaks of H5N1 (Asian flu or bird flu) and H1N1 (swine flu), governments of affected countries spent in excess of 80 billion 
dollars [5]. In addition, influenza is often misdiagnosed making it difficult to accurately assess the financial impact of the disease [6].

Healthy adults are not as susceptible to serious complications as at-risk populations, the oldest, the youngest, people with respiratory pathologies or compromised immune system. In most cases, symptoms are mild and nonspecific such as fever, cough, rhinorrhea, and myalgia. In the most complicated cases, the prescription of antivirals is recommended. Pandemic outbreaks occur occasionally and abruptly, and therefore healthy adults are also at risk. To control flu outbreaks, extreme actions such as restricting traveling or access to public places have been implemented which have a significant impact on the global economy $[7,8]$.

Influenza viruses are divided into different subtypes depending on the antigenic properties of two proteins on their surface, hemagglutinin (HA) and neuraminidase (NA). In principle, it is possible to have combinations of any of the 18 hemagglutinins with 11 described neuraminidases. However, to date, not all have been detected in animals or humans. The diversity of virus subtypes is a major hurdle for vaccine effectiveness as vaccine production takes into account the strains circulating each season, each year [9].

Mutation rates in the influenza virus are high rendering insufficient previously acquired host immunity. The antigenic changes result from two different processes, i.e., antigenic drift and antigenic shift [7]. Antigenic drift results from subtle changes in the influenza virus' genome over time that culminates in a virus of the same strain, but unrecognizable for the host cell immune system. These mutation high rates occur because of the lack of proofreading ability in RNA viruses and it is common in several of these viruses. Unlike antigenic drift, common in several viruses, influenza A viruses (IAV) display a rare ability to undergo antigenic shift [10]. This process, also known as reassortment, occurs occasionally when segments of RNAs from two different strains of IAV infect the same cell allowing their rearrangement into a new viral strain for which most of the population does not have preexisting immunity. A new viral strain can arise due to this genetic event which may display the ability to spread successfully from human-to-human, allowing a new pandemic [11].

In the last one hundred years, the Centers for Disease Control and Prevention (CDC) records have registered four influenza pandemics [12]: 1918, 1957, 1968, and 2009. In the 1918 pandemic, known as the Spanish flu, over one-third of the world's population became infected and 50 million people died, making this the largest influenza pandemic in terms of mortality. Its origin may be traced to the reassortment of a human $\mathrm{H} 1$ and an avian N1 viral subtypes. The 1957 pandemic (Asian flu) caused over 1.1 million deaths from infection by an $\mathrm{H} 2 \mathrm{~N} 2$ viral subtype which resulted from the combination of the H1N1 from the 1918 pandemic with an avian H2N2 subtype. The Asian flu subtype then reassorted with the $\mathrm{H} 3$ avian subtype originating the $\mathrm{H} 3 \mathrm{~N} 2$, responsible for the 1968 pandemic causing over one million victims. The latest pandemic, registered in 2009, resulted from the reassortment of the human H3N2, the swine H1N1, and the avian H1N2 subtypes. This pandemic infected over 60 million people in the United States, killing from 100 to 500 thousand people worldwide [13-15]. The threat of a new pandemic is always present, as shown by the recent situation in China with a H7N9 Asian flu epidemic that was contained after the use of the H7-Re1 vaccine. However, the virus underwent antigenic shift and a new highly pathogenic avian influenza (HPAI) virus was identified last year [16].

To reduce influenza's infections three main approaches are available: vaccination, antiviral drugs, and surveillance. Vaccination is the main preventive response to influenza infections. As mentioned before, vaccines get annual updates according to information from WHO's Global Influenza Surveillance and Response System (GISRS), responsible for data collection and analysis on surveillance, clinical practice, and research around the world [11,13]. When vaccination fails, antiviral drugs are the next alternative. The available antivirals inhibit either the viral matrix protein 2 (M2) [17] (amantadine and rimantadine) or neuraminidases [17] (oseltamivir, zanamivir, laninamivir and peramivir). However, CDC does not recommend the use of the first two for recently circulating influenza viruses due to the high resistance they display towards these drugs; hence neuraminidase inhibitors are the only used in-clinic currently [18]. Usually, these drugs are administered as monotherapy and fall short 
of their therapeutic outcome as they are relatively low in efficacy against seasonal or pandemic flu, only lowering the infection rate [19]. These limitations enhance the need to develop new therapeutic approaches through the knowledge of virus biology and host interactions [20]. Several efforts have been reported to develop new approaches, like monoclonal antibodies, against known targets such as neuraminidase [21] or to identify alternative targets like the nucleoprotein [22] and the polymerase acidic protein (Baloxavir Marboxil) [23].

In this review, we focus on influenza's Non-Structural Protein 1 (NS1). NS1 presents itself as a potential therapeutic target based on two central complementary activities, i.e., counteracting the host's immune response and aiding viral replication [24]. Previous studies on the role of NS1 in the virus biology have shown that viruses without this protein have low rates of replication and dissemination. Thus, the development of therapeutic approaches targeting NS1 could achieve good outcomes in influenza infection treatment [25-27].

\section{The Influenza Virus}

The influenza virus belongs to the Orthomyxoviridae family of virus. There are four types (A, B, $C$ and $D$ ) of influenza virus but only $A, B$, and $C$ infect humans. Human influenza $A$ and $B$ are the virus types responsible for the seasonal flu epidemics, whereas influenza type $\mathrm{C}$ infections generally cause mild illness. Influenza A viruses are the only influenza viruses known to cause flu pandemics. The influenza viruses from types A and B are pleomorphic with size ranging from 80 to $120 \mathrm{~nm}$. Their shape is typically spherical but can acquire a cordlike shape. The C-type influenza viruses are filamentous and can be up to $500 \mathrm{~nm}$ long [28].

As previously mentioned, influenza A viruses are divided into subtypes based on two proteins on the surface of the virus: hemagglutinin (HA) and neuraminidase (NA). Human influenza viruses are named according to their type, subtype, strain number, place, and year of isolation. According to their HA and NA antigenic properties, virus subtypes are named as a combination of 18 different HA subtypes and 11 different NA subtypes, such as HxNy [29,30]. Influenza viruses can differ in pathogenicity and virulence according to their HA:NA ratio, usually around 4:1 [28,31].

Among the different types of influenza, influenza A viruses (IAV) are the most pathogenic for humans. Thus, IAV are the main target for the development of seasonal vaccines to control morbidity and mortality in at-risk populations. IAV have a vast array of hosts including poultry, swine, horses, aquatic mammals, bats, cats, dogs, and birds. Adding to the broad range of species that IAV infect, through antigenic drift and antigenic shift, IAV can acquire the ability to surpass the species barrier. This can allow the emergence of new strains that become a threat to humans [4].

There are two strains of influenza B circulating, B/Victoria/2/1987 and B/Yamagata/16/1988, which arise according to geography. Unlike IAV, the type-B influenza virus is only susceptible to undergo mild, gradual antigenic drift. Influenza $C$ is less dangerous because it lacks neuraminidases on its surface and has a different hemagglutinin, translating into fewer outbreaks and moderate symptoms [29,32].

Structurally, the influenza virion (Figure 1) has an envelope formed by a lipid bilayer embedded with the glycoproteins hemagglutinin (HA) and neuraminidase (NA) which allows the virus to bind to a host cell. M2 is a transmembrane protein that forms proton channels in the viral envelope [32]. The viral matrix protein M1 is membrane associated and forms a rigid matrix layer under the viral envelope. It mediates the encapsidation of RNA-nucleoprotein cores into the membrane envelope. Inside the virion particle, the viral proteins are organized into super-coiled viral ribonucleoproteins (vRNPs) comprising the eight, negative sense, single-stranded ribonucleic acids (RNAs) segments plus a trimeric assembly, the viral polymerase (VP), which includes the polymerase basic protein 1 (PB1), polymerase basic protein 2 (PB2), and polymerase acidic protein (PA). These vRNPs are the central elements in the virus life cycle which are complemented by the host cellular processes [33,34]. 

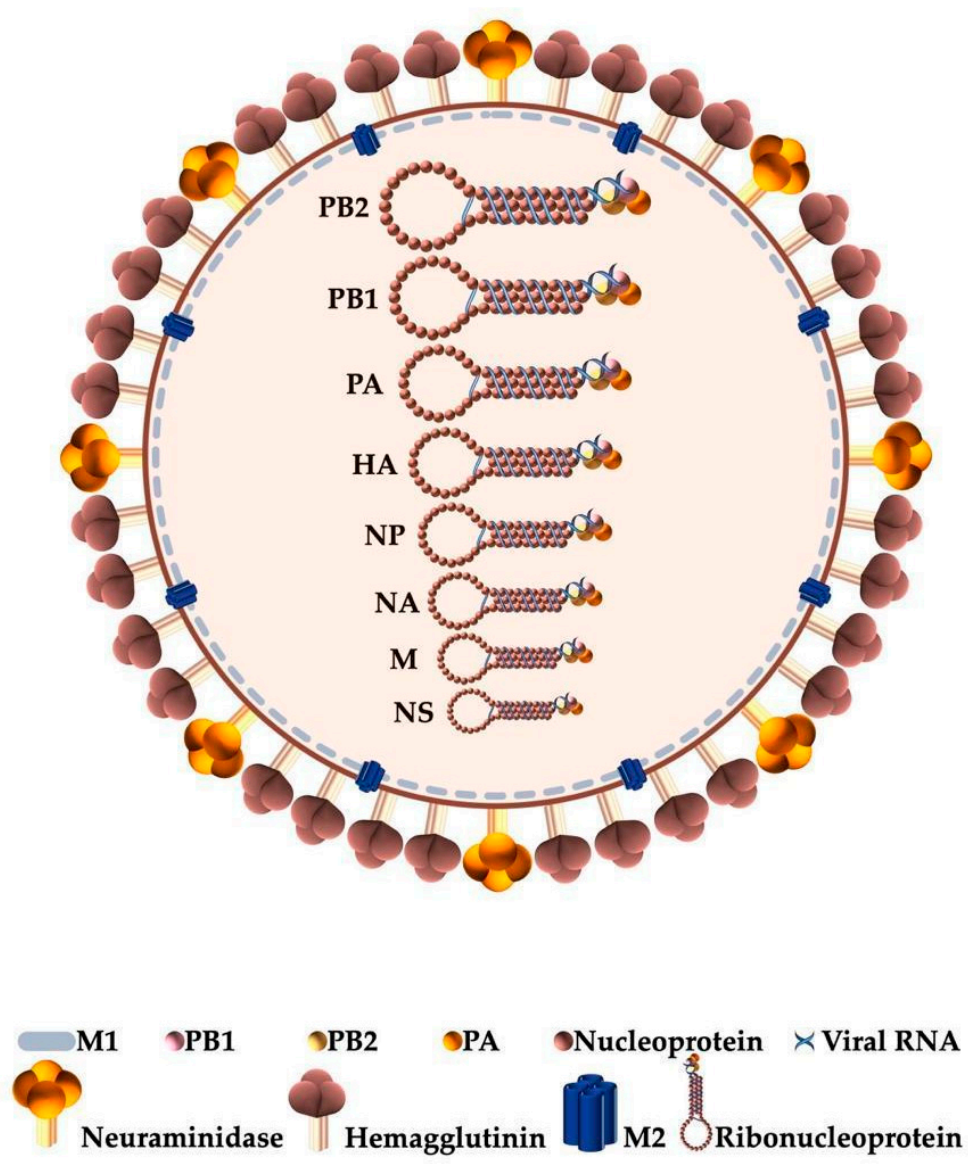

Figure 1. Schematic representation of the influenza virion. The viral genome is depicted highlighting the 8 single-stranded RNA segments (PB2, PB1, PA, HA, NP, NA, M, and NS) organized into ribonucleoproteins and here displayed by their decreasing size. Each ribonucleoprotein complex includes one trimeric viral RNA polymerase (PB1, PB2, and PA), in addition to nucleoproteins wrapped in viral RNA. (M1-viral matrix protein; PB1-polymerase basic protein 1; PB2-polymerase basic protein 2; PA—polymerase acidic protein; M2—ion channel).

A general structure of the influenza virion is depicted in Figure 1.

Table 1 summarizes the function and structure of each protein coded by the eight vRNA segments.

Table 1. Summary of the functions and interactions of the proteins coded by each RNA segment of influenza viruses (aas, amino acids).

\begin{tabular}{|c|c|c|c|}
\hline RNA Segment & Protein(s) Coded & Function $[20,31,35]$ & Structural Data $[20,31,35,36]$ \\
\hline 1 & $\begin{array}{c}\text { PB2 } \\
759 \text { aas }\end{array}$ & $\begin{array}{l}\text { Located in the nucleus of infected cells; } \\
\text { Signals the viral polymerase passage to the } \\
\text { host's nucleus; } \\
\text { Enhances the formation of the cap structures necessary } \\
\text { for viral messenger RNA (mRNA) transcription; } \\
\text { Located in the mitochondria of infected cells [37]; } \\
\text { Inhibits Interferon- } \beta \text {; } \\
\text { Helps determine host range. }\end{array}$ & \multirow{2}{*}{$\begin{array}{l}\text { The three proteins, PB2 (polymerase basic } \\
\text { protein 2), PB1 (polymerase basic protein 1) } \\
\text { and PA (polymerase acidic protein), } \\
\text { form the viral RNA polymerase, responsible } \\
\text { for viral RNA transcription and replication. }\end{array}$} \\
\hline 3 & $\begin{array}{c}\text { PA } \\
716 \text { aas }\end{array}$ & $\begin{array}{l}\text { Functions still unknown, but evidence points to } \\
\text { helicase-like functions; } \\
\text { Important for viral transcription; } \\
\text { Assembly of the polymerase complex. }\end{array}$ & \\
\hline
\end{tabular}


Table 1. Cont.

\begin{tabular}{|c|c|c|c|}
\hline RNA Segment & Protein(s) Coded & Function $[20,31,35]$ & Structural Data $[20,31,35,36]$ \\
\hline 4 & $\begin{array}{c}\text { HA } \\
550 \text { aas }\end{array}$ & $\begin{array}{l}\text { Attaches the virions to the sialic acid (SA) moieties of the } \\
\text { host's receptors; } \\
\text { Around } 30 \% \text { variation between subtypes. }\end{array}$ & $\begin{array}{l}\text { Hemagglutinin (HA) is a homotrimeric } \\
\text { integral cylinder-like membrane } \\
\text { glycoprotein on the virus surface; } \\
4 \text { antigenic sites with direct impact on } \\
\text { virulence and pathogenicity of the virus. }\end{array}$ \\
\hline 5 & $\begin{array}{c}\mathbf{N P} \\
498 \text { aas }\end{array}$ & $\begin{array}{l}\text { Binds non-specifically to single-stranded RNA (ssRNA); } \\
\text { Encapsidates viral RNA; } \\
\text { Helps recruiting RNA polymerase for synthesis of viral } \\
\text { positive-sense RNA (cRNA); } \\
\text { Related to host range. }\end{array}$ & $\begin{array}{l}\text { Nucleoprotein (NP) is a } 56 \mathrm{kDa} \\
\text { basic protein; } \\
\text { RNA-binding protein; } \\
\text { Structural unit of RNPs; } \\
\text { Forms oligomers stabilized by vRNA. }\end{array}$ \\
\hline 6 & $\begin{array}{c}\text { NA } \\
470 \text { aas }\end{array}$ & $\begin{array}{l}\text { Unnecessary for virus replication; } \\
\text { Required for budding of newly formed viral particles } \\
\text { from surface of infected cells; } \\
\text { Facilitates virus movement to the target cell by cleavage } \\
\text { of sialic acids from respiratory tract mucins; } \\
\text { Helps the release of virions from infected cells. }\end{array}$ & $\begin{array}{l}\text { Neuraminidase (NA) is a homotetrameric } \\
\text { integral membrane glycoprotein with } 4 \\
\text { structural domains; } \\
\text { Antigenic sites help circumvent the } \\
\text { immune responses aiding on the virulence } \\
\text { and pathogenicity of the virus. }\end{array}$ \\
\hline 7 & $\begin{array}{c}\text { M2 } \\
97 \text { aas }\end{array}$ & $\begin{array}{l}\text { Vital for viral replication; } \\
\text { Forms proton channel in virus envelope; } \\
\text { Lowers the pH inside the viral particle to promote } \\
\text { uncoating of RNPs; } \\
\text { Modulates Golgi's pH; } \\
\text { Helps to stabilize HA's native conformation } \\
\text { during virus assembly. }\end{array}$ & $\begin{array}{l}\text { Matrix-2 protein (M2) is a 97-residue } \\
\text { single-pass membrane protein; } \\
\text { Three segments: N-terminal outward } \\
\text { segment, transmembrane (TM) helix, } \\
\text { and C-terminal inward segment; } \\
\text { TM helices from } 4 \text { subunits pack to form } \\
\text { proton-channel; } \\
\text { Highly conserved His } 37 \text { and } \\
\text { Trp41 residues. }\end{array}$ \\
\hline
\end{tabular}

In addition to the proteins presented in Table 1, accessory proteins that support regulatory functions in the host or the virus can also be coded depending on the viral strains [38,39].

\section{Non-Structural Protein 1}

\subsection{Structure and Function}

NS1 is a highly conserved [40] and multifunctional protein with approximately $26 \mathrm{kDa}$ molecular weight and 215 to 237 amino acids, resulting from the collinear transcription of the eighth vRNA segment. This viral protein has four different structural regions: two globular domains, a linker region, and a C-terminal disordered "tail". The N-terminal RNA-binding domain (RBD) comprises the first 73 amino acid residues, the effector domain (ED) residue 85 onward until the end of the structured part of NS1, and the C-terminal tail (CTT) is a disordered region with about 20 residues. The linker region (LR), a short and flexible region with a variable number of residues, connects both globular domains [38,39]. NS1 can adopt different conformational states due to the high flexibility and variable composition of the linker region [41]. A schematic view of the structure of the NS1 dimer is depicted in Figure 2. 


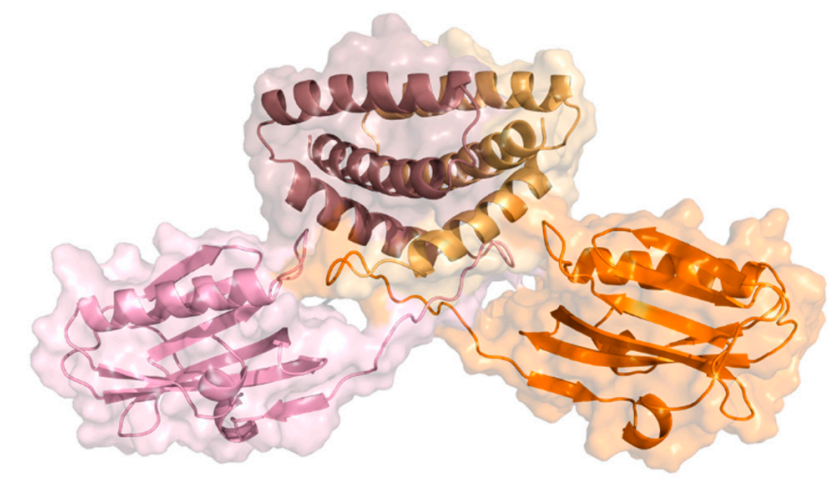

Figure 2. Ribbon and surface representations of the NS1 dimer highlighting its structural domains. Subunits 1 and 2 are represented in pink and orange, respectively; N-terminal RNA-binding domains (RBDs) are represented in dark pink and light orange (top) and effector domains (EDs) in light pink and bright orange (bottom) (PDB ID: 4OPH) [40].

Both X-ray crystallography [42-45] and nuclear magnetic resonance (NMR) [46-49] were used to solve NS1's structure, which is typically represented in its dimeric form $[45,50]$. RBD has two long antiparallel $\alpha$-helices (from Asn4 to Asp24; and Pro31 to Leu50) linked by a short loop and a third helix (from Ile54 to Lys70) before the linker region [50]. To bind to double-stranded RNA (dsRNA), RBD dimerizes forming a group of six antiparallel $\alpha$-helices. A pair of highly conserved Arg38 residues, one per dimer subunit, seem to play a critical role in the interaction with dsRNA, in addition to a charged residue, lysine, at position 41 (Lys41) [38,39]. Some authors propose that binding to dsRNA allows NS1 to assemble into an oligomeric tubular structure that protects the dsRNA molecule, and thus block cellular antiviral processes $[41,43,51]$. The ED has a seven-strand twisted $\beta$-sheet as its main structural element. The structure is comprised by an initial $\beta$-strand in the $\mathrm{N}$-terminus followed by a short helical element, five main antiparallel $\beta$-strands, a $\alpha$-helix across the $\beta$-sheet, and an additional $\beta$-strand before the $\mathrm{C}$-terminus region $[44,46]$.

In cells, full-length NS1 is likely a homodimer [52] with several conformational states as "open", "semi-open", and "closed" [41], depicted in Figure 3A-C, respectively. Previous studies have hypothesized that NS1 conformational states are strain dependent with variations being attributed to different linker sizes and residue composition [41]. However, more recently, evidence has been provided that even in the presence of a shorter linker, it is possible to observe open conformations [53]. Taken the available full-length structures of NS1, it has been proposed that NS1 can shift between different oligomeric conformational states, depending on the function being carried out. This could be related to cellular location, virus lifecycle, or even the presence of different molecular partners with whom NS1 interacts [53].

\subsection{Post-Translational Modifications: Phosphorylation, SUMOylation, and ISGylation}

Several post-translational modifications (PTMs) have been identified in NS1, in particular, phosphorylation, SUMOylation, and ISGylation [54]. NS1 features several phosphorylation sites, namely Thr215, Ser42, and Ser48. From a functional point of view, these PTMs remain to be fully understood. Although phosphorylation in general does not appear to greatly affect viral replication and it is strain dependent, Ser42 phosphorylation makes binding of dsRNA more difficult, and thereby decreases viral replication rates [55-57]. Recent studies showed that phosphorylation may also occur at Thr49, which inhibits NS1's association to TRIM25 and decreases NS1 ability to interfere with the IFN cascade [58]. Another study showed that Thr80 phosphorylation reduces interaction with retinoic acid-inducible gene 1-like receptor dsRNA helicase enzyme (RIG-I) hence making NS1 unable to inhibit the IFN cascade [59]. Some H5N1 subtype strains display a mutation in Asp92 to Glu92 which reduces the strength of the hydrogen bonding interaction between Glu92 Ser195 and Thr197. These two residues (Ser195 and Thr197) are then available to further interact or be phosphorylated 
which translates into a more virulent strain [42]. Moreover, Thr215 can also be phosphorylated and, since, this is nuclear localization signal 2 (NLS2) region, it could lead to disruption of NS1 nuclear location [60].

A.
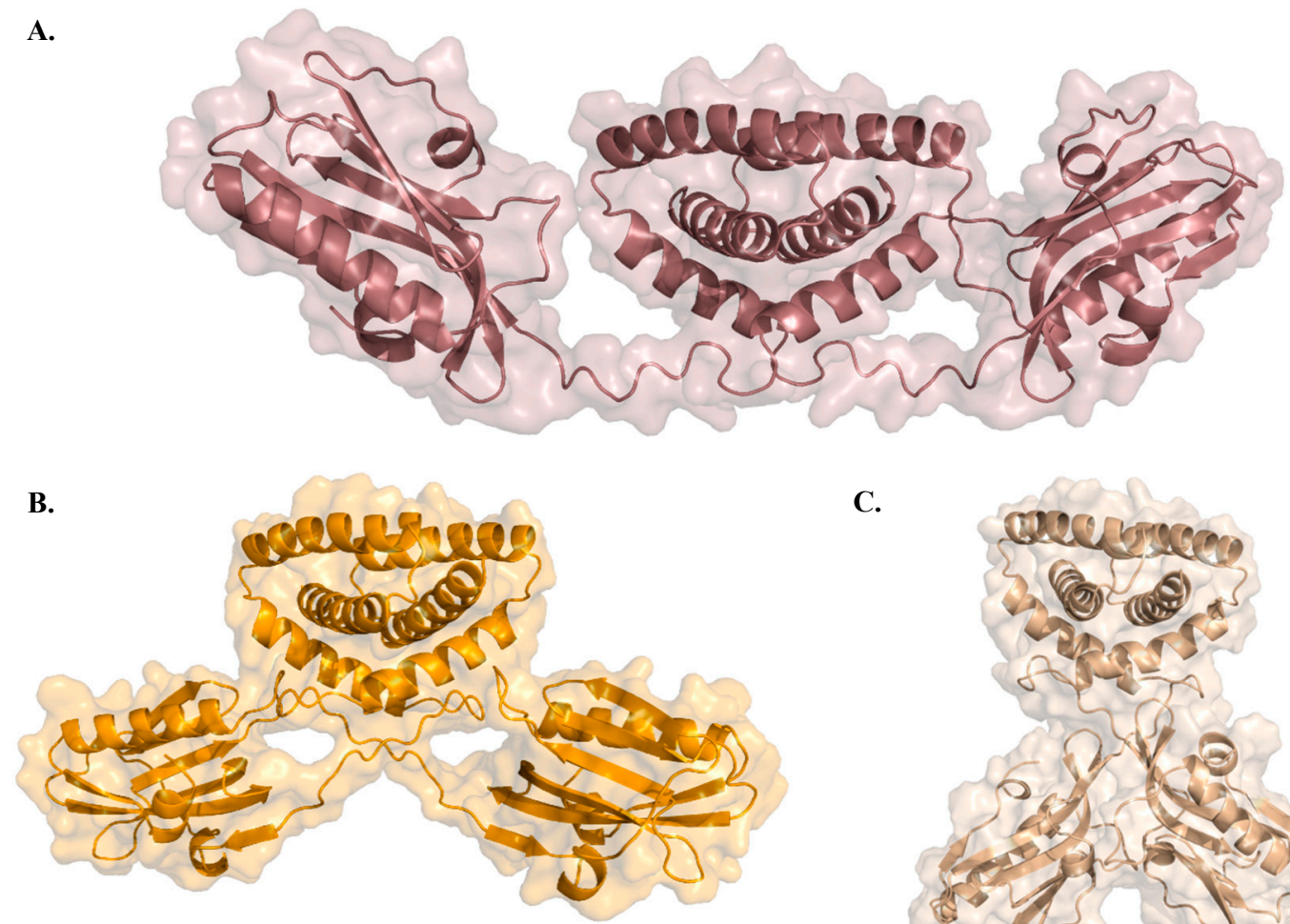

C.

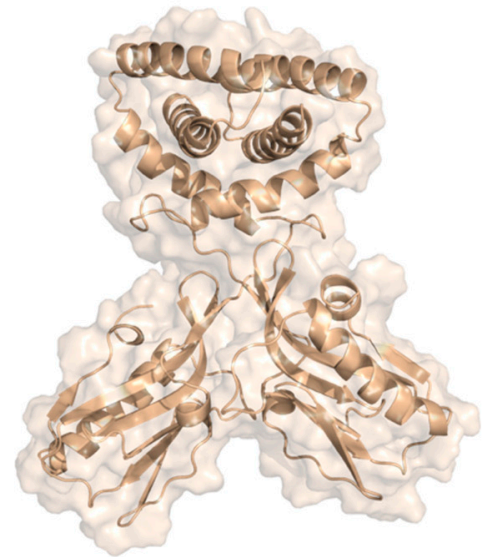

Figure 3. Three X-ray crystallography NS1 structures illustrating the different conformational arrangements of the NS1 dimer: (A) "Open" conformation (PDB ID: 6O01 [53]), (B) "semi-open" conformation (PDB ID: 4OPH [41]), and (C) "closed" conformation (PDB ID: 4OPA [41]).

SUMOylation is a post-translational modification by the SUMO (Small Ubiquitin-like Modifier) family of proteins which is involved in cellular processes like nuclear-cytosolic transport, transcriptional regulation, apoptosis, protein stability, response to stress, and progression through the cell cycle [61]. SUMOylation of NS1 by SUMO1 occurs in residues Lys219 and Lys221, both in the CTT, increasing NS1's stability [55]. If both lysines are replaced by mutation, NS1 decays at a faster rate [62]. Some authors argue that SUMOylation happens not only by SUMO1 but also by SUMO2/3 and that the influenza viruses upregulate SUMOylation since it favors viral multiplication [63]. Lys219 and Lys70, which are conserved residues across viral strains, are crucial to abrogate the IFN signaling pathway associated with SUMOylated NS1. There are multiple potential sites for SUMOylation in NS1, but there seems to exist an intermediate optimal level of SUMOylation for maximal NS1 activity and pathogenic potential [63].

ISGylation, the conjugation of proteins with ISG15 (Interferon-stimulated gene 15 protein), has been demonstrated at several NS1 residues. The ISG15 conjugation system targets Lys41 at the nuclear localization signal 1 (NLS1) on the RBD, blocking NS1's interaction with importin- $\alpha$, critical to nuclear importation, hence decreasing the rate of viral replication [64]. Evidence suggests that Herc5 catalyzes this reaction, which can be especially damaging for NS1's sequences that lack NLS2 in opposition to A/WSN/33 (H0N1) (WSN) viruses or more recent viruses (from 1989) [65]. This residue's modification did not affect the dsRNA binding as its binding site does not superpose with the importin- $\alpha$ binding site [66]. Herc5-mediated ISGylation occurs on other lysine residues inhibiting different functions of NS1 and decreasing the likelihood of homodimer formation by a mechanism still unclear [67]. Influenza A viruses seem to counteract indirectly this effect since their function lowers the IFN levels, which 
consequently lowers ISG15 levels as well [68]. Influenza B viruses can overcome this through the action of E1-like ubiquitin-activating enzyme (Ube1L) that binds to ISG15 blocking it from accomplishing its function [68].

\subsection{Function and Protein-Protein Interactions}

NS1 has a plethora of strategies to inhibit the host immune response due to its ability to establish multiple protein-protein and protein-RNA interactions. NS1 hampers different pathways both in the cytoplasm [69] and in the nucleus of infected cells. The presence of a nuclear export signal (NES) at the C-terminal end of the effector domain allows exiting from the nucleus to the cytoplasm. On the other hand, nuclear localization signals 1 and 2 (NLS1 and NLS2) direct NS1 to the nucleus. While NLS1 is part of the RNA-binding domain N-terminal region allowing NS1 to locate in the nucleoplasm, NLS2 is located in the C-terminal tail allowing NS1 to migrate to the nucleolus [70,71].

Hindering of the IFN induction cell signaling is critical in influenza's infection since production of cytokines like type I interferons is the hosts innate immune prime response to withhold the infection [55]. IFN induction starts by activation of several processes in a cascade and NS1 counteracts them in different ways. RIG-I is active after identification of viral dsRNA leading to ubiquitination of TRIM 25 (tripartite motif-containing protein 25) [72]. As a consequence of this event, RIG-I constitutes an important sensor of influenza's infection [73]. RIG-I binds to NS1 in the same RBD highly conserved site comprising amino acids Arg38 and Lys41, where dsRNA also binds, as depicted in Figure 4 [74]. Although, RIG-I and NS1 form a complex observable by immunoprecipitation, their structural relationship remains unclear [47,72]. Jureka and coworkers recently presented results that show the importance of NS1 Arg21 in RIG-I's activation and that its mutation to glutamine inhibits RIG-I binding. Nonetheless, this point mutation has no effect on TRIM25 nor dsRNA binding [75].

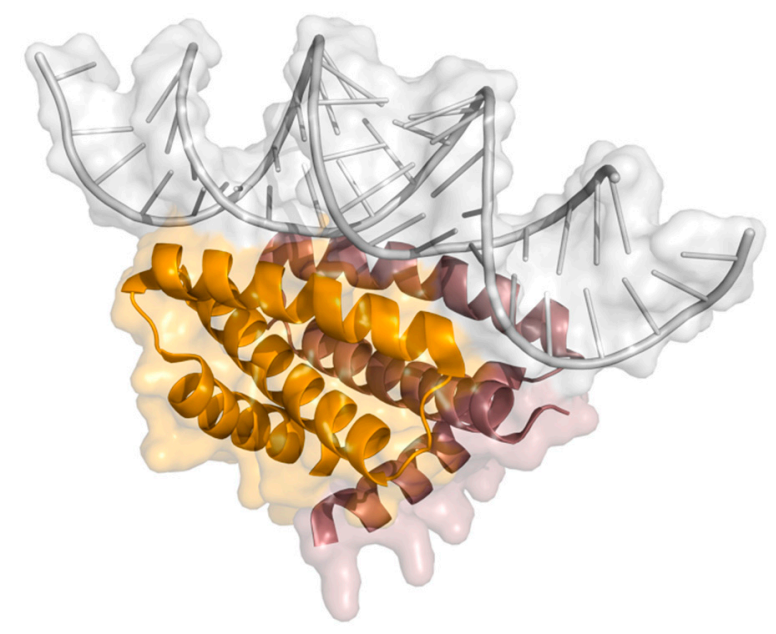

Figure 4. X-ray structure of RNA binding domain of NS1 bound to dsRNA (PDB ID: 2ZKO) [76] (orange, NS1-RBD monomer 1; pink, NS1-RBD monomer 2; gray, dsRNA).

TRIM25 [77], a ubiquitin ligase, and riplet [78] are essential for IFN production and promote RIG-I's ubiquitination. NS1 is able to bind to both these proteins, enhancing its IFN's inhibitory action. NS1 binds to TRIM25 (Figure 5) preventing the RIG-I's ubiquitination [79]. Structural studies by Koliopoulos and coworkers also show that NS1 oligomers can cross-link different molecules of TRIM25 [80].

Recently, Wang and collaborators identified two residues essential for NS1's contribution to viral pathogenicity and its cell concentration. Mutation of Ser212 to proline in avian H7N9 decreases the NS1 ability to stop the host's IFN response and to enhance viral replication. Likewise, mutation of Ile178 to valine prompted NS1 degradation through the proteasome pathway [81]. 


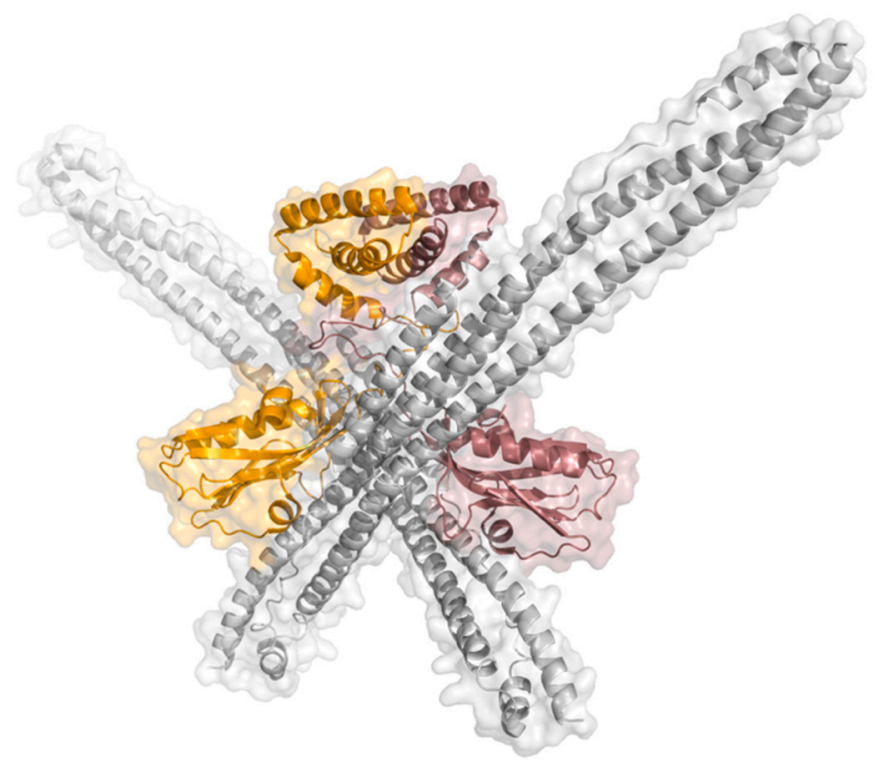

Figure 5. X-ray structure of NS1 dimer bound to TRIM25's coiled-coil domain (PDB ID: 5NT2) [80] (orange, NS1 monomer 1; pink, NS1 monomer 2; gray, TRIM25's coiled-coil domain).

Additionally, NS1 also attenuates the expression of host genes by interfering with the pre-mRNA processing machinery [82]. NS1 binds CPSF30 preventing polyadenylation of the host's IFN pre-mRNA, leading to its accumulation in the nucleus and inhibiting expression of the IFN genes or IFN-related genes [83]. The polyadenylation of the viral mRNAs is not affected since it relies on the viral polymerase [84]. Binding to CPSF30 (Figure 6) also enables inhibition of mRNA transport from the nucleus to the cytoplasm and mRNA splicing [85]. It was suggested that the build-up of pre-mRNA in the nucleus is a source for cap snatching by the viral polymerase [86]. NS1 has a globally hydrophobic pocket comprising residues Lys110, Ile117, Ile119, Gln121, Val180, Gly183, Gly184 and Trp187, where NS1 binds to two (F2 and F3) of the five zinc fingers of CPSF30 [40]. Outside of this binding pocket, two residues, Phe103 and Met106, maintain the stability of the interaction [87]. As a consequence of the binding to CPSF30, NS1's Trp187 is inaccessible, blocking NS1's ED-ED dimerization [60]. Residues in the CTT mediate PABPII binding [88], preventing poly-adenine tail extension of mRNAs, and thus preventing nuclear export [89]. Other nuclear mRNA export factors, such as NXF1, p15, Rae1, E1B-AP5, and Nup98, have also been reported to bind to NS1 [90,91]. Taking into account all these interactions, it becomes clear the relevance of NS1 in inhibiting the antiviral response of the host cell, as well as, the interference on the effective communication between neighboring cells.

NS1 inhibits double-stranded RNA-activated protein kinase (PKR), 2', 5' -oligoadenylate synthetase (OAS), ribonuclease L (RNAse L), and phosphoinositide 3-kinase (PI3K) of the host cell, interfering with multiple cellular pathways. PKR is a kinase from the eukaryotic initiation factor $2 \alpha$ (eIF2 $\alpha$ ) that, after activation by dsRNAs, inhibits translation, a critical aspect harmful to viral growth. In previous studies, the interface for the NS1-PKR binding was thought to comprise residues Ile123 and Asn127 [92] which would block PKR's conformational change needed for dsRNA binding [93]. Recent studies have shown that NS1 residues Arg35 and Arg36 are involved in the direct binding of NS1 and PKR, blocking PKR's activation and enhancing the influenza's virulence [94]. The affinity of NS1 to dsRNA is high enough to overcome in vivo competition with OAS. This means that NS1 binds preferentially to dsRNA instead of binding to OAS. This could indicate that the primary function of dsRNA binding is to make it unavailable to OAS, hence, stopping the IFN cascade by the activation of RNAse L through OAS [95]. 


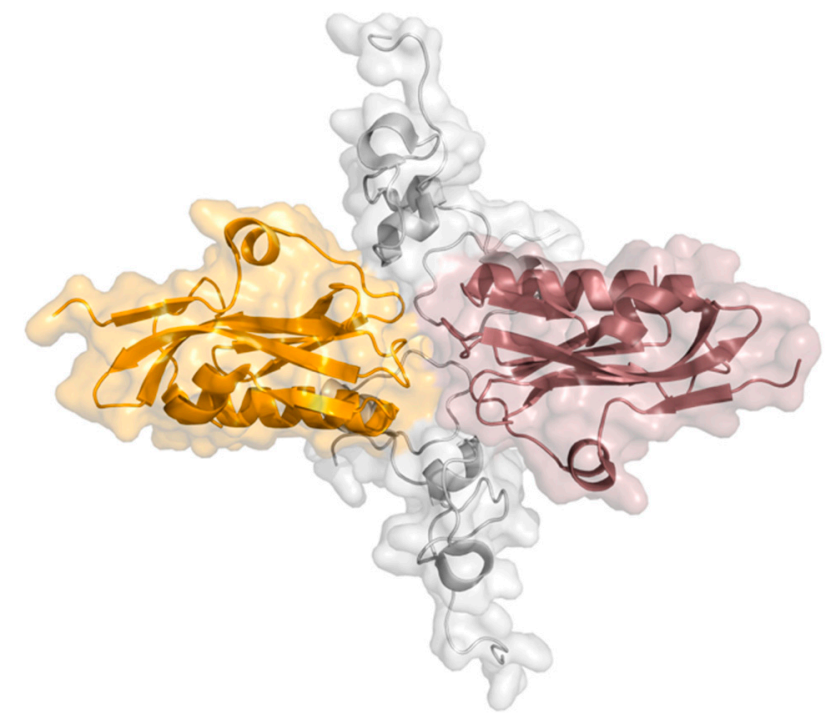

Figure 6. X-ray structure of NS1 effector domain bound to CPSF30's F2F3 finger (PDB ID: 2RHK) [87] (orange, NS1-ED monomer 1; pink, NS1-ED monomer 2; gray, CPSF30's F2F3 finger).

To enhance pro viral responses, viruses have different strategies such as delaying apoptosis through PI3K activation, an important checkpoint for cellular homeostasis [96]. NS1 interacts with the $\mathrm{SH}_{2}$ domains of the $\mathrm{p} 85 \beta$ subunit of PI3K via residues Tyr89 and Pro164. It has been suggested that the dimerization of the ED is not necessary for the interaction with PI3K [97]. Recently, additional NS1 interactions have been proposed, such as the one with nucleolar RNA helicase 2 (DDX21). This protein inhibits viral polymerase (VP) aggregation by PB1 viral subunit binding. Due to NS1's binding to DDX21, VP is then able to assemble all the subunits (PA, PB1 and PB2) and continue to catalyze viral RNA synthesis [98]. NS1 also binds to the 5'UTR of viral mRNAs, translation initiation factor 4G1 (elF4G1) (amino acids 81 to 113) [99], and polyadenine binding protein I (PABPI) [100] forming a heterotrimeric complex that inhibits viral translation. Cytoplasmic polysomes were found to contain NS1 and hStaufen, a protein involved in the transport of mRNAs to the active translation sites [101]. $\mathrm{Zhu}$, Zheng, and collaborators had recently unveiled the interaction of NS1 with the nucleolar and coiled-body phosphoprotein (NOLC1). The authors observed that, after binding, there was an increase in apoptosis of host cells, which seems counterintuitive considering the role of NS1 in the viral cycle, and thus awaits future clarification [102].

For a more holistic understanding of the multitude of virus-host interactions, data intensive approaches such as interactomics will play a role. Shapira and coworkers [103] found that NS1 promotes up-regulation of 45 virus-specific regulated genes (VSRGs) from which 24 have an important role in viral replication or the host's IFN response. DeChassey and coworkers [104] got an extensive interactome of both NS1 and NS2, identifying more than 560 interactions and 33 proteins that interacted only with NS1. These intricate interaction network maps help to delineate novel strategies to use NS1 as a potential therapeutic target. Raman and coworkers [105] developed an interactome of NS1 in pigs which could be evaluated for human applicability. They identified 192 proteins (92 already documented), some were new interactors like heterogeneous ribonucleoprotein particles (hnRNPs) $\mathrm{C}, \mathrm{K}$ and $\mathrm{U}$, interleukin enhancer-binding factor 3 (ILF3), and ATP-dependent RNA helicase (DDX1), while others like PABPI, DEAx box helicase 9 (DHX9), DDX21, and Crk-like protein L (CrkL) got confirmation in this study. Recently, another interactome analysis of NS1 showed that, in addition to all the PPIs already described, NS1 is involved in the splicing the pre-mRNA through binding to the pre-mRNA-processing factor 19 (PRP19). This new interaction should be further studied in order to assess its relevance for viral pathogenicity, since the same study showed that cells without endogenous PRP19 also showed decreased IAV replication [106]. 
NS1 has gained motifs in its CTT which have conferred to NS1 the ability to interact with a wider collection of proteins [107]. There is evidence in the literature that NS1 may interact with the following additional partners: human PAF1 transcription elongation complex (hPAF1C); parafibromin (CDC73), global transcription activator (SNF2L) [108]; chromodomain-helicase-DNA-binding protein 1 (CHD1) [109]; WD repeat-containing protein-5 (WDR5) [109]; $\beta$-tubulin [110]; nucleolin, fibrillarin, and nuclear B23 [70]; RNA-associated protein 55 (RAP55) [111]; RNA binding protein nuclear factor 90 (NF90) [112]; heat shock protein 90 (HSP90) [113]; NOD-like receptor family, pyrin domain containing 3 protein (NLRP3) [114]; inhibitor of nuclear factor kappa-B kinase subunits $\alpha$ and $\beta$ (IKK $\alpha$ and IKK $\beta$ ) [115]; poly(a)-binding protein II (PABII) [89]; human guanylate-binding protein 1 (hGBP1) [116]; transcription factors p53 and cleavage and polyadenylation specificity factor subunit 4 (CPSF4) [117]; PDZ and LIM domain protein 2 (PDlim2) [118]; membrane-associated guanylate kinase inverted 1, 2 and 3 (MAGI-1,2 and 3, respectively), scribble and discs large homolog 1 (Dlg-1) [119,120]; tyrosine-protein kinase Src (c-Src), tyrosine-protein phosphatase non-receptor type 1 (PTPL1) and reversion-induced LIM protein (RIL) [121]; and adapter molecule crk (CrkI and CrkII) [107].

It remains to be seen, among the multitude of interactions reported (Figure 7), which are relevant in vivo and at what stages of the virus life cycle. But the general evidence coming out of all these interactions mediated by NS1 points to pathways that enhance viral replication, while maintaining the host's immune response weakened.
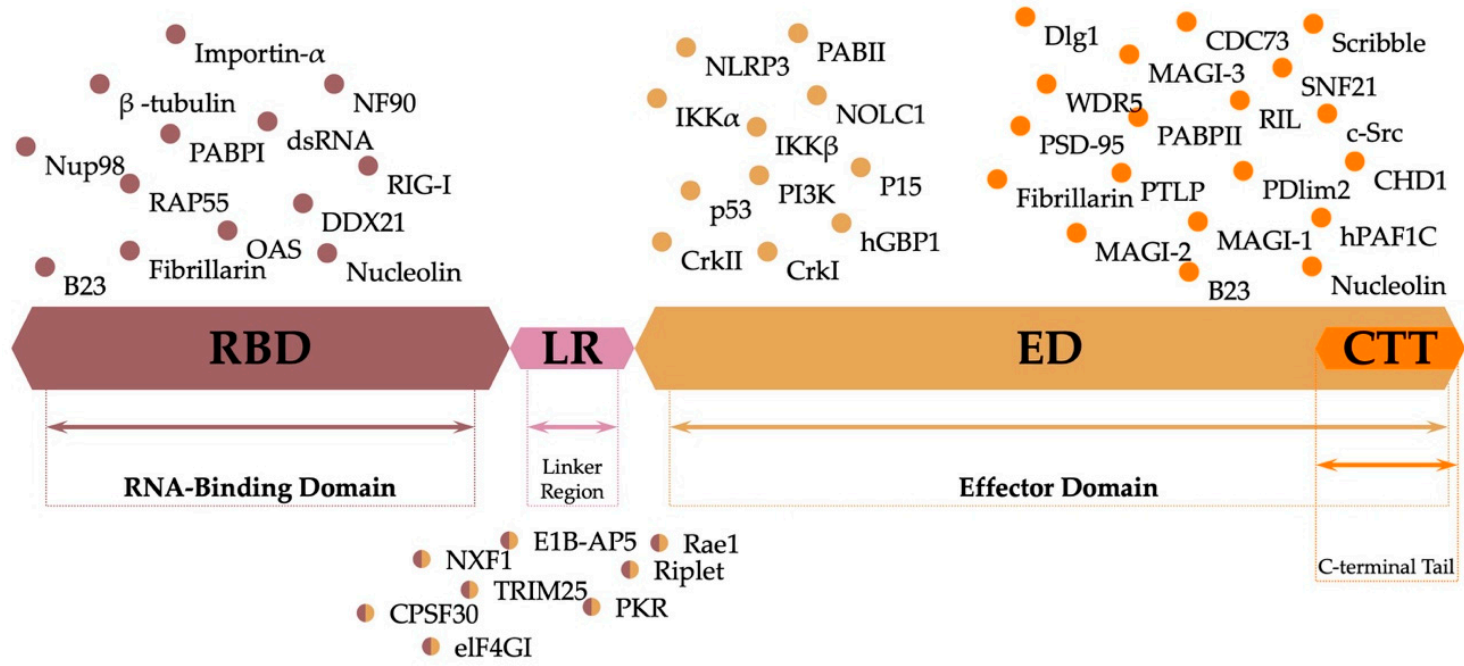

Interaction partners with unknown binding location: hnRNP C, hnRNP U, hnRNP K, NS1-BP, PARP10, DDX1, Gas8, hStaufen, p53, Hsp90, ILF3, PACT, DDX3

Figure 7. Graphical representation of known NS1 protein-protein and protein-RNA interactions and their respective site of interaction. (all proteins and interactions mentioned in the figure are referenced in the text).

\subsection{NS1: Target to Manage Influenza Outbreaks}

\subsubsection{NS1-Modified Virus as Vaccines}

NS1 has been related to increased pathogenicity and virulence of influenza. Viruses that fail to express NS1 may cause less severe symptoms and show decreased ability to proliferate. For example, the IFN cascade is not as affected and will perform normally under lack of NS1 expression in the host's cells. NS gene truncations or deletions translate into attenuated viruses [122] as confirmed by a H1N1 influenza strain which lacked the NS1 reading frame ( $\triangle$ NS1-H1N1) and was tested successfully as an intranasal vaccine in Phase I clinical trials with healthy adult volunteers [123]. Following this study, serum and nasal wash analysis for IgA revealed that it can neutralize influenza's viruses not only from 
the subtype H1N1, but also from H3N2 and H5N1 subtypes. IgG, on the other hand, is only effective on the subtype tested, H1N1 [124].

A different study used a delNS1-H5N1 as a live attenuated vaccine virus. After an intranasal monovalent dose, results revealed its safety and tolerability. Moreover, $75 \%$ of the participants displayed seroconversion after one immunization and $\operatorname{IgA}$ serum levels were increased after a second immunization [125].

In addition to the abovementioned studies, a trivalent vaccine succeeded in Phase I/II trials. An intranasal vaccine formulation was used for a delNS1-trivalent vaccine comprising the strains H1N1, H3N2 from influenza A viruses and a type-B influenza strain. Similarly to other clinical trials, this vaccine was also safe and well tolerated and IgA levels were also increased as expected [126].

\subsubsection{Experimental and In Silico Approaches Towards a New Therapeutic Path}

Vaccination is the first approach to prevent influenza episodes, but prevention only goes so far, as explained previously. The second most used method against influenza outbreaks is the use of antiviral drugs. M2 inhibitors, known as adamantanes (amantadine and rimantadine) have limitations due to increased resistance among the IAV. Although some strains are also becoming resistant to the most used neuraminidase inhibitors (oseltamivir, zanamivir, and paramivir), these are still prescribed in critical infection cases, high-risk groups, or hospitalized patients [23].

With the high viral mutation rates and resistance-related problems associated with the commonly used therapeutic targets, the key to the development of new antivirals is the identification of novel therapeutic targets [127]. In this context, NS1 presents itself as a promising target due to its multifunctional nature and central role in virus biology and infection mechanisms. Thus, it is key to pinpoint all the relevant interactions and ligand-binding sites in NS1 to enable the discovery of small molecules with the goal of developing new therapies [24]. One of the most relevant characteristics of NS1 to be considered is its ability to inhibit the innate immune response of the host, restricting the cascade response of IFN at different levels and increasing the level of virulence of the influenza virus [128]. One way to decrease NS1 expression is through the use of small interfering RNAs (siRNAs). This approach strictly marks viral genes with zero impact on host pathways and expression, which should decrease undesirable side effects and toxic effects [129]. Wu and coworkers synthesized three antisense RNA oligonucleotides targeting the NS gene, and each one worked individually well in vitro. However, in vivo the results were not very promising. The authors recognized that the results were improved when the three sequences were used simultaneously. Rajput and coworkers [130] tried to mute NS genes post-transcriptionally by administering wild type (WT) siRNAs in vivo. Their results showed that siRNAs could strongly inhibit viral replication, justifying this as a valuable approach applicable to antiviral drugs that aim to inhibit NS1 indirectly.

Some proteins and peptides, in particular antibodies (Abs), were found to effectively and specifically inhibit NS1's activity. The monoclonal antibody (mAb) D9 was able to interact with an avian influenza virus' epitope of NS1, although not inhibiting it [131]. Still, regarding avian influenza, several other mAbs were found to bind to virus' proteins, in particular, NS1 [132]. In a different study, $\mathrm{mAb} 2 \mathrm{H} 6$ was found to bind to NS1, inhibiting the interaction between NS1 and double-stranded RNA [112]. Avian influenza was also tested with $11 \mathrm{mAbs}$, four of them anti-NS1 mAbs which showed reactivity against recombinant NS1 [133].

Rational discovery and design of new lead compounds for therapy development is significantly helped by the knowledge of the high-resolution three-dimensional structure of the therapeutic target. In the case of NS1, several structures of the full-length protein and its functional domains (RBD and ED) are available at the Protein Data Bank (PDB) [134]. Among the 44 NS1 structures available to date (February 2020), several are in complex with different molecular partners-dsRNA or other proteins. This multitude of examples helps in the identification of NS1 main interaction sites and thus in the discovery and design of inhibitors of these interactions. Both experimental and in silico methods may 
be used to identify suitable ligands for NS1 by blocking NS1 activity or preventing some key interaction, and thus allowing the identification of potential lead compounds and drug candidates [135].

Regarding drug design, NS1 is a target to be considered due to its involvement in multiple essential pathways in influenza's biology [135]. NS1 was initially identified as a viable target through yeast-based screening assays with 2000 compounds. Of these, four compounds emerged capable of inhibiting NS1 activity. Initially, Basu and coworkers [136] conducted a study aiming at identifying compounds able to block NS1 activity without having repercussions on the hosts' proliferation. As NS1 is toxic to yeast, the NS1 inhibitor is as successful as the yeast cells regain their normal growth [137]. It was found that three compounds (NSC128164, NSC109834, and NSC95676) decreased the levels of NS1-specific viral RNAs. Another compound (NSC125044), although not interfering with the viral RNAs levels, increased IFN's induction. These four compounds seem to act on two different antiviral mechanisms. This yeast-based assay showed that it is possible to target accurately NS1 and that the action on NS1 decreased the virus load. The action of these compounds is restricted to specific interactions with influenza's NS1, as activity in other viruses has not been inhibited. These results proved that NS1 may be a target for small molecule inhibitors with clinical applicability. Walkiewicz and coworkers [138] pursued one of these four compounds to further investigate how it modulates NS1's action, optimizing the prior hits. One of these compounds-JJ3297-was shown to inhibit viral replication by shifting the IFN signaling cascade into regaining its normal function. This is important if the infection is in its early stages because JJ3297 is effective in restoring the IFN cascade, preventing the spread of the infection to neighboring cells. However, the compound is less effective if the infection has already spread to a high cell number. The mechanism of action of JJ3297 remains unclear, but it seems to be related to the essential presence of RNAse $\mathrm{L}$.

In 2012, another compound-NSC125044—was tested by Jablonski and coworkers [139] for activity evaluation of the molecule's core after stripping it of accessory regions, and a structure-activity relationship (SAR) was established. Using a live cell virus replication assay, the authors concluded that the best SAR for this binding site was represented by a chemical entity with a large hydrophobic core with a weakly basic function on its left-hand side, whereas the right-hand side should have an aromatic ring linked by an amide bond before a short methylene chain. In this study, A9 and A22, small molecules that are derivatives of NSC125044, were the most promising molecules, A22 being 10 times more potent than A9. Recently, Kleinpeter and coworkers [140] continued Jablonski's research [139]. Both molecules bind to NS1-ED and, by mapping the interaction region through X-ray crystallography, it was shown that they share the same binding pocket as CPSF30, meaning that these compounds can act as inhibitors of the NS1-CPSF30 interaction.

In addition, the ML303 family of compounds was passed onto in vivo studies carried out by Patnaik and coworkers [141]. This pyrazolopyridine family of compounds is a group of NS1 antagonists and exhibited rehabilitation of the IFN cascade, previously inhibited by NS1, and a remarkable antiviral activity in-cell culture. Another study using yeast-based assays was conducted by Kong and coworkers [142] targeting NS1's interaction with CPSF30. They tested Chinese medicine substances to assess if they could inhibit this interaction site. The most promising results came from an oral liquid substance called "Shuanghualian".

Other authors performed high-throughput screening (HTS) assays, using fluorescence polarization (FP) [143-145] and radiolabeled RNA [146], to identify inhibitors of NS1's interaction with dsRNA. Mata and coworkers [143] studied a naphthalimide family of compounds to identify if they could revert the function of NS1 in blocking the replication machinery of the host. They concluded that these compounds could be used as upregulators of hypoxia-inducible factor-1 (REDD1), a mammalian target of rapamycin complex 1 (mTORC1) inhibitor, which is a defense factor [147]. Cho and coworkers [144] carried out a FP-based screening study that identified six promising molecules as NS1 inhibitors. Epigallocatechin gallate (EGCG) was selected as the most effective using a minimal dosage. They proposed that EGCG interferes with the binding of dsRNA to NS1 because it interacts with Arg38, which is essential for dsRNA binding. You and coworkers [145] also used FP-based assays 
to test a family of quinoxalines, which share a bicyclic ring with the ability to incorporate polar side chains. They conducted a SAR study concluding that two compounds were effective at binding to the NS1 dsRNA binding domain, inhibiting the binding of dsRNA. Martínez-Gil and coworkers [148] tried a different approach. After high-throughput screening, compound C3 came up as a potential candidate against influenza's infections since its effect of increasing IFN levels was not affected by NS1, apparently because it activated a different pathway or because it acted downstream of NS1's targets. This molecule seems promising as a broad-spectrum antiviral since its action is not NS1 dependent, but, instead, IFN inductive. Maroto and coworkers [146] used radiolabeled RNA to check if the NS1's binding site to vRNA could be a new antiviral drug target and, if so, to identify some contenders. They analyzed 27,520 compounds and three of them could decrease NS1-vRNA binding proving that this could be a target for new drugs.

Virtual screenings have also helped in the discovery of hit compounds. CPSF30 is involved in direct pre-mRNA processing and has its activity altered due to NS1 [149]. On the basis of this assumption, a study was conducted using molecular docking and molecular dynamics, starting with more than 30,000 initial compounds [150]. This study allowed the selection of two compounds capable of inhibiting the activity of NS1 related to CPSF30. Another study performed a docking-based screening of 200,000 compounds with AUTODOCK [151]. The authors picked two compounds to proceed out of 17 hits with positive outcome. These compounds displayed the ability to inhibit the activation of an antiviral pathway by interfering with NS1's interaction with dsRNA [152].

Although NS1 establishes interactions with multiple molecular partners, the interaction between NS1 and dsRNA is one of the most explored. Molecular dynamics (MD) simulations and free energy calculations have been used to understand the molecular basis of dsRNA recognition by NS1 [153]. Free energy calculations can be performed by combining molecular mechanics with Poisson-Boltzmann surface area (MM/PBSA) or generalized Born surface area (MM/GBSA) calculations. This approach allows the estimation of ligand-binding affinities by combining molecular mechanics and continuum solvation models [154]. MD simulations were also used to explore potential interactions of NS1 with membrane proteins [155], an approach that might help in the understanding of the overall process involving the virus and virion interactions with the host cell [156]. Table 2 summarizes the main aspects of the studies mentioned above.

Table 2. Summary of studies exploring influenza's NS1 as potential therapeutic target.

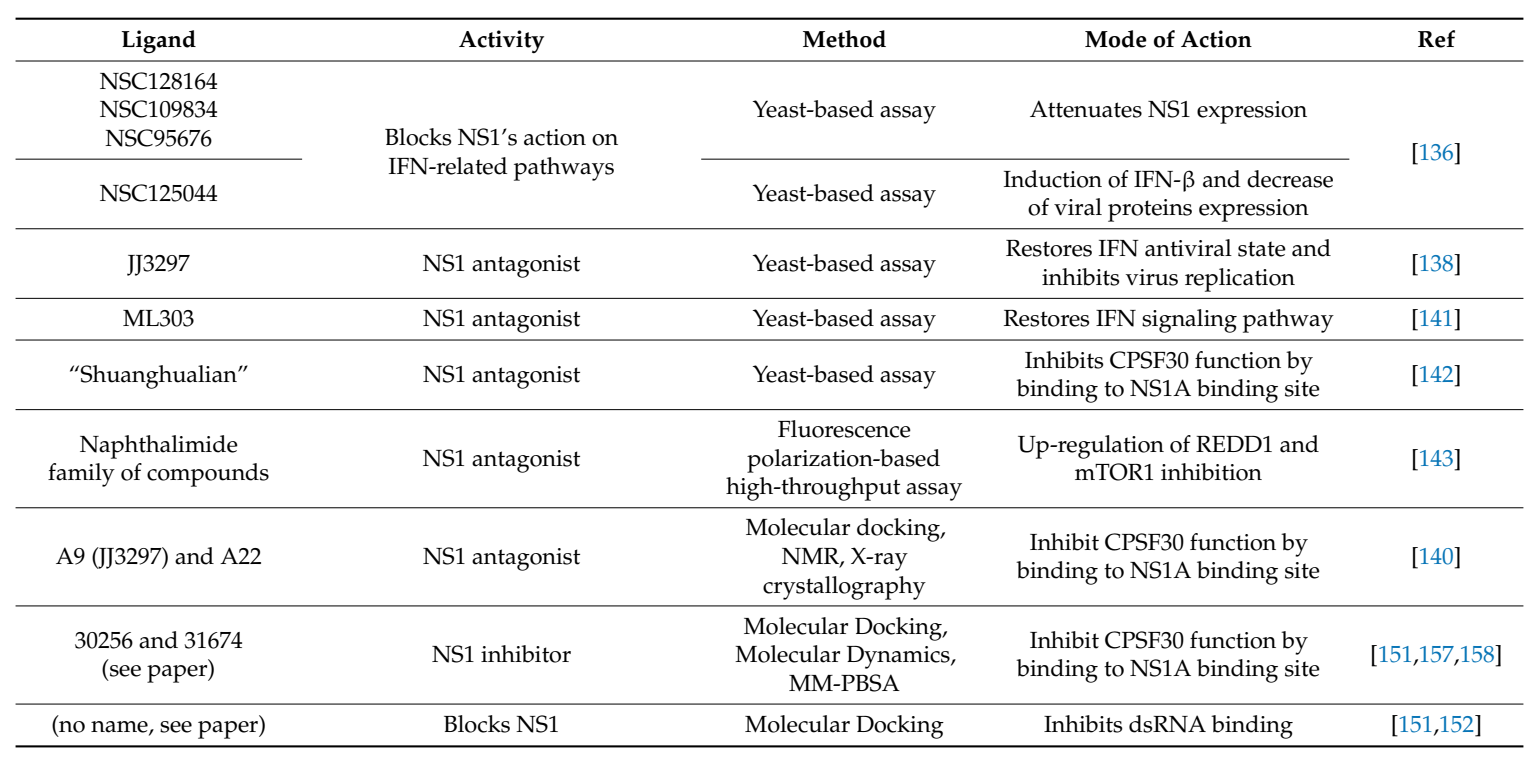


Table 2. Cont.

\begin{tabular}{|c|c|c|c|c|}
\hline Ligand & Activity & Method & Mode of Action & Ref \\
\hline $\begin{array}{l}\text { Epigallocatechin } \\
\text { gallate (EGCG) }\end{array}$ & Proposed binding to NS1's Arg38 & $\begin{array}{c}\text { Fluorescence } \\
\text { polarization-based } \\
\text { high-throughput assay }\end{array}$ & Inhibits dsRNA binding & [144] \\
\hline $\begin{array}{l}\text { Quinoxaline } \\
\text { family of compounds }\end{array}$ & NS1 inhibitor & $\begin{array}{c}\text { Fluorescence } \\
\text { polarization-based } \\
\text { high-throughput assay }\end{array}$ & Inhibit dsRNA binding & [145] \\
\hline C3 & Counteracts IFN blockage by NS1 & $\begin{array}{c}\text { Caspase 3-based } \\
\text { high-throughput assay }\end{array}$ & IFN-induction & [148] \\
\hline $\mathrm{mAb}$ & $\begin{array}{l}\text { Binds selectively to NS1 of avian } \\
\text { influenza virus }\end{array}$ & $\begin{array}{l}\text { Antigen screening using } \\
\text { recombinant peptides }\end{array}$ & Recognition of NS1's presence & [132] \\
\hline $\mathrm{mAb}$ & $\begin{array}{c}\text { Binds to Thr49 region of NS1 of } \\
\text { avian influenza virus }\end{array}$ & $\begin{array}{c}\text { Enzyme-Linked } \\
\text { Immunosorbent Assay } \\
\text { (ELISA), surface } \\
\text { plasmon resonance }\end{array}$ & $\begin{array}{l}\text { Interferes with the virus ability } \\
\text { to replicate }\end{array}$ & [159] \\
\hline
\end{tabular}

\subsubsection{NS1's Role in Influenza's Host Tropism}

Host tropism refers to the specificity of some pathogens to infect particular hosts or host tissues. Molecular and biological characteristics of the host organism determine host tropism, i.e., the ability of a virus to interact with a particular characteristic of a host. In the case of influenza virus, quantitative analysis of surface interacting molecules and immunohistochemistry assays stand central to the understanding of host tropism, although other approaches should not be neglected [160]. Computational approaches like data mining and machine learning (ML) have been used. For example, random forests $(\mathrm{RF})$ was used to build 11 computational models from sequences of proteins isolated from influenza, producing highly accurate prediction models capable of determining the host tropism of individual influenza proteins. In this study, NS1 was predicted to have a large number of interactions with different hosts (high host tropism) [161].

Influenza viruses, in particular, have a high risk of being transmitted through animal carriers (zoonotic risk [162]). The distinction in host tropism protein signatures can be used to train ML prediction models for zoonotic strain prediction. Using a dataset consisting of 13,998 strains of the influenza A virus from the Influenza Research Database [163], after removing invalid sequences of the 11 proteins, NS1 included, host tropism signature features were transformed from the protein sequence to yield 146 feature vectors comprising several amino acid-based characteristics. This dataset was then used to train an RF prediction model, i.e., an ensemble of decision trees trained with randomly selected features and instances that were then combined with a bagging algorithm to maximize the value of the information on the dataset. This model can predict the zoonotic classification of the virus (in this case, avian, human, or zoonotic), and thus could be eventually used as a predictive tool with social, economic and public health impact [161].

Due to their ability to evade species barriers influenza strains have been detected in a larger number of different host's species [164]. Thus, tackling influenza infections and pandemics requires the knowledge of the host range of different virus strains. In a recent study, a multi-host dataset of 674 different influenza strains organized into three host categories (avian, human, and swine) was compiled. The authors multi-labelled the sequences depending on the host's species they were isolated from and their parent-strains. For example, if a human isolated virus reassortment occurred from both avian and swine parent-strains, then, the new strain would be labelled as avian, swine and human. This dataset ended up with seven different classifications: avian, human, swine, human-swine, human-avian, avian-swine, and human-avian-swine. This classification enabled the representation of the host range for each sequence through multi-label learning, i.e., the possibility of each sequence to belong to more than one individual class. Finally, the dataset was trained using different ML models, 
such as decision trees, and it was possible to pinpoint the most discriminative and combinatorial positions, regarding the host range. NS1 was one of the proteins associated with high human host range [165].

\section{Conclusions}

The morbidity and mortality associated with seasonal flu epidemics have a significant social and economic impact in contemporary societies, being from the large number of missed working days per year, or even more significantly from the increase in mortality of senior citizens and other high-risk groups. Moreover, the permanent and latent menace of a flu pandemic threatens the safety and way of life in our societies. The inefficient coverage provided by flu vaccines and the rapid development of resistance against the known antivirals by many influenza strains, highlights the need for new antivirals directed against novel biological targets.

Non-structural protein 1 (NS1), the subject of this review, plays a key role in influenza virus biology and mechanisms of infection through a multitude of molecular interaction partners, host cell activities, and structural plasticity or polymorphism. These multiple functions are mediated by multiple molecular interactions and various binding spots or pockets that could be targeted to develop novel antiviral therapies. NS1-directed antivirals could eventually be used in monotherapy or as part of combination therapies allowing synergistic effects against resistant strains [166].

In addition to the knowledge on the molecular mechanisms of action of influenza proteins, the characterization of host tropism of influenza virus needs also to be addressed with the aim of predicting the viral strains with higher probability of successful zoonotic transmission. Regarding host tropism, the importance of NS1 has also been highlighted and shown to directly influence the host range through its action on interferon response [161,167].

Progresses in the structural and functional characterization of influenza's NS1 should pave the way for a more holistic understanding of this protein, and thus chart new paths for more efficacious ways of combating influenza outbreaks. Lead and tool compounds directed to NS1 have been identified, allowing validation of the protein as a potential therapeutic target. The coming years will see the discovery of new compounds and eventually the progress to the clinical setting of inhibitors of influenza's NS1.

Author Contributions: Conceptualization, N.R.-F.; data curation and research, N.R.-F. and A.J.P.; fund raising, R.M.M.B; writing — original draft preparation, N.R.-F. and A.J.P.; supervision, R.M.M.B. and I.S.M.; writing—review and editing, R.M., I.S.M., and R.M.M.B. All authors have read and agreed to the published version of the manuscript.

Funding: Support for this work was obtained through projects PTDC/QUI-OUT/32572/2017: Leads4Flu (to RMMB), CENTRO-01-0145-FEDER-000008: BrainHealth 2020, and POCI-01-0145-FEDER-007440, financed by the European Regional Development Fund (ERDF), Centro 2020 Regional Operational Programme, COMPETE 2020—Operational Programme for Competitiveness and Internationalisation, and Portuguese national funds via Fundação para a Ciência e Tecnologia (FCT). The work developed by R. Melo was supported by FCT through project PTDC/QUI-OUT/32243/2017. Irina S. Moreira was funded by the FCT Investigator programme-IF/00578/2014 (co-financed by the European Social Fund and Programa Operacional Potencial Humano), the COMPETE 2020-Operational Programme for Competitiveness and Internationalisation and Portuguese national funds via FCT_Fundação para a Ciência e a Tecnologia, under projects POCI-01-0145-FEDER-031356, PTDC/QUI-OUT/32243/2017, PTDC/QUI-OUT/32572/2017 and UIDB/04539/2020.

Acknowledgments: Nícia Rosário-Ferreira and António José Preto acknowledge support from Fundação da Ciência e Tecnologia (FCT), Portugal, under the doctoral fellowships PD/BD/135179/2017 and SFRH/BD/144966/2019, respectively.

Conflicts of Interest: The authors declare no conflict of interest. The funding agencies had no role in the design of the study; in the collection, analyzes, or interpretation of data; in the writing of the manuscript, or in the decision to publish the results. 


\section{References}

1. Thompson, W.W.; Weintraub, E.; Dhankhar, P.; Cheng, P.-Y.; Brammer, L.; Meltzer, M.I.; Bresee, J.S.; Shay, D.K. Estimates of US Influenza-Associated Deaths Made Using Four Different Methods. Influenza Other Respir. Viruses 2009, 3, 37-49. [CrossRef]

2. Iuliano, A.D.; Roguski, K.M.; Chang, H.H.; Muscatello, D.J.; Palekar, R.; Tempia, S.; Cohen, C.; Gran, J.M.; Schanzer, D.; Cowling, B.J.; et al. Estimates of Global Seasonal Influenza-Associated Respiratory Mortality: A Modelling Study. Lancet 2018, 391, 1285-1300. [CrossRef]

3. Molinari, N.-A.; Ortega-Sanchez, I.R.; Messonnier, M.L.; Thompson, W.W.; Wortley, P.M.; Weintraub, E.; Bridges, C.B. The Annual Impact of Seasonal Influenza in the US: Measuring Disease Burden and Costs. Vaccine 2007, 25, 5086-5096. [CrossRef]

4. Webster, R.G.; Monto, A.S.; Braciale, T.J.; Lamb, R.A. Textbook of Influenza; John Wiley \& Sons: Hoboken, NJ, USA, 2014.

5. Zambon, M. Influenza and Other Emerging Respiratory Viruses. Medicine 2014, 42, 45-51. [CrossRef]

6. Nicoll, A.; Ciancio, B.C.; Lopez Chavarrias, V.; Mølbak, K.; Pebody, R.; Pedzinski, B.; Penttinen, P.; van der Sande, M.; Snacken, R.; van Kerkhove, M.D. Influenza-Related Deaths. Available Methods for Estimating Numbers and Detecting Patterns for Seasonal and Pandemic Influenza in Europe. Eurosurveillance 2012, 17, 1-13. [CrossRef] [PubMed]

7. Bisen, P.S.; Raghuvanshi, R. Emerging Epidemics: Management and Control, 1st ed.; Wiley-Blackwell: Hoboken, NJ, USA, 2013.

8. Centers for Disease Control and Prevention. How Is Pandemic Flu Different from Seasonal Flu? Available online: https://www.cdc.gov/flu/pandemic-resources/basics/about.html (accessed on 15 June 2019).

9. Mubareka, S.; Palese, P. Influenza Virus: The Biology of a Changing Virus. In Influenza Vaccines for the Future; Rappuoli, R., Del Giudice, G., Eds.; Springer Basel: Basel, Switzerland, 2011; pp. 3-26.

10. Carrat, F.; Flahaul, A. Influenza Vaccine: The Challenge of Antigenic Drift. Vaccine 2007, 25, $6852-6862$. [CrossRef] [PubMed]

11. Paules, C.; Subbarao, K. Influenza. Lancet 2017, 390, 697-708. [CrossRef]

12. Centers for Disease Control and Prevention. Past Pandemics. Available online: https://www.cdc.gov/flu/ pandemic-resources/basics/past-pandemics.html (accessed on 15 June 2019).

13. Hussain, M.; Galvin, H.; Haw, T.Y.; Nutsford, A.; Husain, M. Drug Resistance in Influenza A Virus: The Epidemiology and Management. Infect. Drug Resist. 2017, 10, 121-134. [CrossRef]

14. Kilbourne, E.D. Influenza Pandemics of the 20th Century. Emerg. Infect. Dis. 2006, 12, 9-14. [CrossRef]

15. Dawood, F.S.; Iuliano, A.D.; Reed, C.; Meltzer, M.I.; Shay, D.K.; Cheng, P.-Y.; Bandaranayake, D.; Breiman, R.F.; Brooks, W.A.; Buchy, P.; et al. Estimated Global Mortality Associated with the First 12 Months of 2009 Pandemic Influenza A H1N1 Virus Circulation: A Modelling Study. Lancet Infect. Dis. 2012, 12, 687-695. [CrossRef]

16. Jiang, W.; Hou, G.; Li, J.; Peng, C.; Wang, S.; Liu, S.; Zhuang, Q.; Yuan, L.; Yu, X.; Li, Y.; et al. Antigenic Variant of Highly Pathogenic Avian Influenza A(H7N9) Virus, China, 2019. Emerg. Infect. Dis. 2020, 26, 379-380. [CrossRef] [PubMed]

17. Aoki, F.Y.; Allen, U.D.; Stiver, H.G.; Evans, G.A. The Use of Antiviral Drugs for Influenza: Guidance for Practitioners 2012/2013. Can. J. Infect. Dis. Med. Microbiol. 2012, 23, e79-e92. [CrossRef] [PubMed]

18. Hsieh, H.-P.; Hsu, J. Strategies of Development of Antiviral Agents Directed Against Influenza Virus Replication. Curr. Pharm. Des. 2007, 13, 3531-3542. [CrossRef] [PubMed]

19. Gasparini, R.; Amicizia, D.; Lai, P.L.; Bragazzi, N.L.; Panatto, D. Compounds with Anti-Influenza Activity: Present and Future of Strategies for the Optimal Treatment and Management of Influenza. Part II: Future Compounds against Influenza Virus. J. Prev. Med. Hyg. 2014, 55, 109-129.

20. Das, K.; Aramini, J.M.; Ma, L.-C.; Krug, R.M.; Arnold, E. Structures of Influenza A Proteins and Insights into Antiviral Drug Targets. Nat. Struct. Mol. Biol. 2010, 17, 530-538. [CrossRef]

21. Stadlbauer, D.; Zhu, X.; McMahon, M.; Turner, J.S.; Wohlbold, T.J.; Schmitz, A.J.; Strohmeier, S.; Yu, W.; Nachbagauer, R.; Mudd, P.A.; et al. Broadly Protective Human Antibodies That Target the Active Site of Influenza Virus Neuraminidase. Science 2019, 366, 499-504. [CrossRef]

22. Hu, Y.; Sneyd, H.; Dekant, R.; Wang, J. Functional Viral Protein As a Hot Antiviral Drug Target. Curr. Top. Med. Chem. 2018, 17, 2271-2285. 
23. Beigel, J.H.; Hayden, F.G. Influenza Therapeutics in Clinical Practice-Challenges and Recent Advances. Cold Spring Harb. Perspect. Med. 2020, a038463. [CrossRef]

24. Engel, D.A. The Influenza Virus NS1 Protein as a Therapeutic Target. Antivir. Res. 2013, 99, 409-416. [CrossRef]

25. Talon, J.; Horvath, C.M.; Polley, R.; Basler, C.F.; Muster, T.; Palese, P.; Garcia-Sastre, A. Activation of Interferon Regulatory Factor 3 Is Inhibited by the Influenza A Virus NS1 Protein. J. Virol. 2000, 74, 7989-7996. [CrossRef]

26. García-Sastre, A. Induction and Evasion of Type I Interferon Responses by Influenza Viruses. Virus Res. 2011, 162, 12-18. [CrossRef] [PubMed]

27. García-Sastre, A. Inhibition of Interferon-Mediated Antiviral Responses by Influenza A Viruses and Other Negative-Strand RNA Viruses. Virology 2001, 279, 375-384. [CrossRef] [PubMed]

28. Gasparini, R.; Amicizia, D.; Lai, P.L.; Bragazzi, N.L.; Panatto, D. Compounds with Anti-Influenza Activity: Present and Future of Strategies for the Optimal Treatment and Management of Influenza. Part I: Influenza Life-Cycle and Currently Available Drugs. J. Prev. Med. Hyg. 2014, 55, 69-85. [PubMed]

29. Rappuoli, R.; Del Giudice, G. Influenza Vaccines for the Future; Springer Science \& Business Media: Berlin, Germany, 2010; p. 363. [CrossRef]

30. CDC. Influenza, 13th ed.; Hamborsky, J., Kroger, A., Wolfe, S., Eds.; Public Health Foundation: Washington, DC, USA, 2015.

31. Abbas, M.; Abidin, Z.U. Proteins of Influenza Virus: A Review. J. Infect. Mol. Biol. 2013, 1, 1-7.

32. Samji, T. Influenza A: Understanding the Viral Life Cycle. Yale J. Biol. Med. 2009, 82, 153-159.

33. Anastasina, M. Influenza A Virus-Host Interactions and Their Control by Viral Non-Structural Protein NS1. Ph.D. Thesis, University of Helsinki, Helsinki, Finland, 2015.

34. Eisfeld, A.J.; Neumann, G.; Kawaoka, Y. At the Centre: Influenza A Virus Ribonucleoproteins. Nat. Rev. Microbiol. 2015, 13, 28-41. [CrossRef]

35. Xia, S. High Throughput Screening of Inhibitors for Influenza Protein NS1. Ph.D. Thesis, University of Texas at Austin, Austin, TX, USA, 2009.

36. Du, J.; Cross, T.A.; Zhou, H.X. Recent Progress in Structure-Based Anti-Influenza Drug Design. Drug Discov. Today 2012, 17, 1111-1120. [CrossRef]

37. Long, J.C.D.; Fodor, E. The PB2 Subunit of the Influenza A Virus RNA Polymerase Is Imported into the Mitochondrial Matrix. J. Virol. 2016, 90, 8729-8738. [CrossRef]

38. Chen, W.; Calvo, P.A.; Malide, D.; Gibbs, J.; Schubert, U.; Bacik, I.; Basta, S.; O’Neill, R.; Schickli, J.; Palese, P.; et al. A Novel Influenza A Virus Mitochondrial Protein That Induces Cell Death. Nat. Med. 2001, 7, 1306-1312. [CrossRef]

39. Hale, B.G.; Batty, I.H.; Downes, C.P.; Randall, R.E. Binding of Influenza A Virus NS1 Protein to the Inter-SH2 Domain of P85 $\beta$ Suggests a Novel Mechanism for Phosphoinositide 3-Kinase Activation. J. Biol. Chem. 2008, 283, 1372-1380. [CrossRef]

40. Trigueiro-Louro, J.M.; Correia, V.; Santos, L.A.; Guedes, R.C.; Brito, R.M.M.; Rebelo-de-Andrade, H. To Hit or Not to Hit: Large-Scale Sequence Analysis and Structure Characterization of Influenza A NS1 Unlocks New Antiviral Target Potential. Virology 2019, 535, 297-307. [CrossRef] [PubMed]

41. Carrillo, B.; Choi, J.-M.; Bornholdt, Z.A.; Sankaran, B.; Rice, A.P.; Prasad, B.V.V. The Influenza A Virus Protein NS1 Displays Structural Polymorphism. J. Virol. 2014, 88, 4113-4122. [CrossRef] [PubMed]

42. Bornholdt, Z.A.; Prasad, B.V.V. X-Ray Structure of Influenza Virus NS1 Effector Domain. Nat. Struct. Mol. Biol. 2006, 13, 559-560. [CrossRef] [PubMed]

43. Bornholdt, Z.A.; Prasad, B.V.V. X-Ray Structure of NS1 from a Highly Pathogenic H5N1 Influenza Virus. Nature 2008, 456, 985-988. [CrossRef] [PubMed]

44. Xia, S.; Robertus, J.D. X-Ray Structures of NS1 Effector Domain Mutants. Arch. Biochem. Biophys. 2010, 494, 198-204. [CrossRef]

45. Yin, C.; Khan, J.A.; Swapna, G.V.T.; Ertekin, A.; Krug, R.M.; Tong, L.; Montelione, G.T. Conserved Surface Features Form the Double-Stranded RNA Binding Site of Non-Structural Protein 1 (NS1) from Influenza A and B Viruses. J. Biol. Chem. 2007, 282, 20584-20592. [CrossRef]

46. Shen, Q.; Cho, J.-H. The Structure and Conformational Plasticity of the Nonstructural Protein 1 of the 1918 Influenza A Virus. Biochem. Biophys. Res. Commun. 2019, 518, 178-182. [CrossRef]

47. Jureka, A.S.; Kleinpeter, A.B.; Cornilescu, G.; Cornilescu, C.C.; Petit, C.M. Structural Basis for a Novel Interaction between the NS1 Protein Derived from the 1918 Influenza Virus and RIG-I. Structure 2015, 23, 2001-2010. [CrossRef] 
48. Aramini, J.M.; Ma, L.; Lee, H.; Zhao, L.; Cunningham, K.; Ciccosanti, C.; Janjua, H.; Fang, Y.; Xiao, R.; Krug, R.M. Solution NMR Structure of the Monomeric W187R Mutant of A/Udorn NS1 Effector Domain. Northeast Struct. Genomics Target OR8C [W187R] J. 2009. [CrossRef]

49. Tamada, T.; Kitadokoro, K.; Higuchi, Y.; Inaka, K.; Yasui, A.; de Ruiter, P.; Eker, A.P.M.; Miki, K.; Chien, C.Y.; Tejero, R.; et al. A Novel RNA-Binding Motif in Influenza A Virus Non-Structural Protein 1. Nat. Struct. Biol. 1997, 4, 891-895.

50. Chien, C.; Xu, Y.; Xiao, R.; Aramini, J.M.; Sahasrabudhe, P.V.; Krug, R.M.; Montelione, G.T. Biophysical Characterization of the Complex between Double-Stranded RNA and the N-Terminal Domain of the NS1 Protein from Influenza A Virus: Evidence for a Novel RNA-Binding Mode. Biochemistry 2004, 43, 1950-1962. [CrossRef] [PubMed]

51. Darapaneni, V.; Prabhaker, V.K.; Kukol, A. Large-Scale Analysis of Influenza A Virus Sequences Reveals Potential Drug Target Sites of Non-Structural Proteins. J. Gen. Virol. 2009, 90, 2124-2133. [CrossRef] [PubMed]

52. Nemeroff, M.E.; Qian, X.-Y.; Krug, R.M. The Influenza Virus NS1 Protein Forms Multimers in Vitro and in Vivo. Virology 1995, 212, 422-428. [CrossRef] [PubMed]

53. Mitra, S.; Kumar, D.; Hu, L.; Sankaran, B.; Moosa, M.M.; Rice, A.P.; Ferreon, J.C.; Ferreon, A.C.M.; Prasad, B.V.V. Influenza A Virus Protein NS1 Exhibits Strain-Independent Conformational Plasticity. J. Virol. 2019. [CrossRef]

54. Klemm, C.; Boergeling, Y.; Ludwig, S.; Ehrhardt, C. Immunomodulatory Nonstructural Proteins of Influenza A Viruses. Trends Microbiol. 2018, 26, 624-636. [CrossRef]

55. Krug, R.M.; García-Sastre, A. The NS1 Protein: A Master Regulator of Host and Viral Functions. In Textbook of Influenza; Webster, R.G., Monto, A.S., Braciale, T.J., Lamb, R.A., Eds.; John Wiley \& Sons, Ltd.: Oxford, UK, 2013.

56. Hale, B.G.; Knebel, A.; Botting, C.H.; Galloway, C.S.; Precious, B.L.; Jackson, D.; Elliott, R.M.; Randall, R.E. CDK/ERK-Mediated Phosphorylation of the Human Influenza A Virus NS1 Protein at Threonine-215. Virology 2009, 383, 6-11. [CrossRef]

57. Hsiang, T.-Y.; Zhou, L.; Krug, R.M. Roles of the Phosphorylation of Specific Serines and Threonines in the NS1 Protein of Human Influenza A. Viruses. J. Virol. 2012, 86, 10370-10376. [CrossRef]

58. Kathum, O.A.; Schräder, T.; Anhlan, D.; Nordhoff, C.; Liedmann, S.; Pande, A.; Mellmann, A.; Ehrhardt, C.; Wixler, V.; Ludwig, S. Phosphorylation of Influenza A Virus NS1 Protein at Threonine 49 Suppresses Its Interferon Antagonistic Activity. Cell. Microbiol. 2016, 18, 784-791. [CrossRef]

59. Zheng, W.; Cao, S.; Chen, C.; Li, J.; Zhang, S.; Jiang, J.; Niu, Y.; Fan, W.; Li, Y.; Bi, Y.; et al. Threonine 80 Phosphorylation of Non-Structural Protein 1 Regulates the Replication of Influenza A Virus by Reducing the Binding Affinity with RIG-I. Cell. Microbiol. 2017, 19, e12643. [CrossRef]

60. Hale, B.G.; Randall, R.E.; Ortin, J.; Jackson, D. The Multifunctional NS1 Protein of Influenza A Viruses. J. Gen. Virol. 2008, 89, 2359-2376. [CrossRef]

61. Hay, R.T. SUMO. Mol. Cell 2005, 18, 1-12. [CrossRef]

62. Xu, K.; Klenk, C.; Liu, B.; Keiner, B.; Cheng, J.; Zheng, B.-J.; Li, L.; Han, Q.; Wang, C.; Li, T.; et al. Modification of Nonstructural Protein 1 of Influenza A Virus by SUMO1. J. Virol. 2011, 85, 1086-1098. [CrossRef]

63. Santos, A.; Pal, S.; Chacon, J.; Meraz, K.; Gonzalez, J.; Prieto, K.; Rosas-Acosta, G. SUMOylation Affects the Interferon Blocking Activity of the Influenza A Nonstructural Protein NS1 without Affecting Its Stability or Cellular Localization. J. Virol. 2013, 87, 5602-5620. [CrossRef] [PubMed]

64. Marc, D. Influenza Virus Non-Structural Protein NS1: Interferon Antagonism and Beyond. J. Gen. Virol. 2014, 95, 2594-2611. [CrossRef] [PubMed]

65. Melen, K.; Kinnunen, L.; Fagerlund, R.; Ikonen, N.; Twu, K.Y.; Krug, R.M.; Julkunen, I. Nuclear and Nucleolar Targeting of Influenza A Virus NS1 Protein: Striking Differences between Different Virus Subtypes. J. Virol. 2007, 81, 5995-6006. [CrossRef] [PubMed]

66. Zhao, C.; Hsiang, T.-Y.; Kuo, R.-L.; Krug, R.M. ISG15 Conjugation System Targets the Viral NS1 Protein in Influenza A Virus-Infected Cells. Proc. Natl. Acad. Sci. USA 2010, 107, 2253-2258. [CrossRef] [PubMed]

67. Tang, Y.; Zhong, G.; Zhu, L.; Liu, X.; Shan, Y.; Feng, H.; Bu, Z.; Chen, H.; Wang, C. Herc5 Attenuates Influenza A Virus by Catalyzing ISGylation of Viral NS1 Protein. J. Immunol. 2010, 184, 5777-5790. [CrossRef]

68. Yuan, W. Influenza B Virus NS1 Protein Inhibits Conjugation of the Interferon (IFN)-Induced Ubiquitin-like ISG15 Protein. EMBO J. 2001, 20, 362-371. [CrossRef]

69. Greenspan, D.; Palese, P.; Krystal, M. Two Nuclear Location Signals in the Influenza Virus NS1 Nonstructural Protein. J. Virol. 1988, 62, 3020-3026. [CrossRef] 
70. Melén, K.; Tynell, J.; Fagerlund, R.; Roussel, P.; Hernandez-Verdun, D.; Julkunen, I. Influenza A H3N2 Subtype Virus NS1 Protein Targets into the Nucleus and Binds Primarily via Its C-Terminal NLS2/NoLS to Nucleolin and Fibrillarin. Virol. J. 2012, 9, 167. [CrossRef]

71. Li, Y.; Yamakita, Y.; Krug, R.M. Regulation of a Nuclear Export Signal by an Adjacent Inhibitory Sequence: The Effector Domain of the Influenza Virus NS1 Protein. Proc. Natl. Acad. Sci. USA 1998, 95, 4864-4869. [CrossRef] [PubMed]

72. Pichlmair, A.; Schulz, O.; Tan, C.P.; Naslund, T.I.; Liljestrom, P.; Weber, F.; Reis e Sousa, C. RIG-I-Mediated Antiviral Responses to Single-Stranded RNA Bearing 5'-Phosphates. Science 2006, 314, 997-1001. [CrossRef] [PubMed]

73. Jahan, A.S.; Biquand, E.; Muñoz-Moreno, R.; Le Quang, A.; Mok, C.K.-P.; Wong, H.H.; Teo, Q.W.; Valkenburg, S.A.; Chin, A.W.H.; Man Poon, L.L.; et al. OTUB1 Is a Key Regulator of RIG-I-Dependent Immune Signaling and Is Targeted for Proteasomal Degradation by Influenza A NS1. Cell Rep. 2020, 30, 1570-1584. [CrossRef] [PubMed]

74. Wang, W.; Riedel, K.; Lynch, P.; Chien, C.; Montelione, G.; Krug, R.M. RNA Binding by the Novel Helical Domain of the Influenza Virus NS1 Protein Requires Its Dimer Structure and a Small Number of Specific Basic Amino Acids. RNA 1999, 5, S1355838299981621. [CrossRef]

75. Jureka, A.S.; Kleinpeter, A.B.; Tipper, J.L.; Harrod, K.S.; Petit, C.M. The Influenza NS1 Protein Modulates RIG-I Activation via a Strain-Specific Direct Interaction with the Second CARD of RIG-I. J. Biol. Chem. 2020, 295, 1153-1164. [CrossRef]

76. Cheng, A.; Wong, S.M.; Yuan, Y.A. Structural Basis for DsRNA Recognition by NS1 Protein of Influenza A Virus. Cell Res. 2009, 19, 187-195. [CrossRef]

77. Gack, M.U.; Albrecht, R.A.; Urano, T.; Inn, K.-S.; Huang, I.-C.; Carnero, E.; Farzan, M.; Inoue, S.; Jung, J.U.; García-Sastre, A. Influenza A Virus NS1 Targets the Ubiquitin Ligase TRIM25 to Evade Recognition by the Host Viral RNA Sensor RIG-I. Cell Host Microbe 2009, 5, 439-449. [CrossRef]

78. Oshiumi, H.; Miyashita, M.; Inoue, N.; Okabe, M.; Matsumoto, M.; Seya, T. The Ubiquitin Ligase Riplet Is Essential for RIG-I-Dependent Innate Immune Responses to RNA Virus Infection. Cell Host Microbe 2010, 8 , 496-509. [CrossRef]

79. Martín-Vicente, M.; Medrano, L.M.; Resino, S.; García-Sastre, A.; Martínez, I. TRIM25 in the Regulation of the Antiviral Innate Immunity. Front. Immunol. 2017, 8, 1-9. [CrossRef]

80. Koliopoulos, M.G.; Lethier, M.; van der Veen, A.G.; Haubrich, K.; Hennig, J.; Kowalinski, E.; Stevens, R.V.; Martin, S.R.; Reis e Sousa, C.; Cusack, S.; et al. Molecular Mechanism of Influenza A NS1-Mediated TRIM25 Recognition and Inhibition. Nat. Commun. 2018, 9, 1820. [CrossRef]

81. Wang, S.; Zhang, L.; Zhang, R.; Chi, X.; Yang, Z.; Xie, Y.; Shu, S.; Liao, Y.; Chen, J.L. Identification of Two Residues within the NS1 of H7N9 Influenza A Virus That Critically Affect the Protein Stability and Function 11 Medical and Health Sciences 1108 Medical Microbiology 06 Biological Sciences 0601 Biochemistry and Cell Biology. Vet. Res. 2018, 49, 1-14.

82. Nogales, A.; Martinez-Sobrido, L.; Topham, D.J.; Dediego, M.L. Modulation of Innate Immune Responses by the Influenza a NS1 and PA-X Proteins. Viruses 2018, 10, 708. [CrossRef] [PubMed]

83. Ayllon, J.; García-Sastre, A. The NS1 Protein: A Multitasking Virulence Factor. Curr. Top. Microbiol. Immunol. 2015, 386, 73-107. [PubMed]

84. Robertson, J.S.; Schubert, M.; Lazzarini, R.A. Polyadenylation Sites for Influenza Virus MRNA. J. Virol. 1981, 38, 157-163. [CrossRef] [PubMed]

85. Fortes, P.; Beloso, A.; Ortín, J. Influenza Virus NS1 Protein Inhibits Pre-MRNA Splicing and Blocks MRNA Nucleocytoplasmic Transport. EMBO J. 1994, 13, 704-712. [CrossRef]

86. Nemeroff, M.E.; Barabino, S.M.L.; Li, Y.; Keller, W.; Krug, R.M. Influenza Virus NS1 Protein Interacts with the Cellular 30 KDa Subunit of CPSF and Inhibits 3' End Formation of Cellular Pre-MRNAs. Mol. Cell 1998, 1, 991-1000. [CrossRef]

87. Das, K.; Ma, L.-C.; Xiao, R.; Radvansky, B.; Aramini, J.; Zhao, L.; Marklund, J.; Kuo, R.-L.; Twu, K.Y.; Arnold, E.; et al. Structural Basis for Suppression of a Host Antiviral Response by Influenza A Virus. Proc. Natl. Acad. Sci. USA 2008, 105, 13093-13098. [CrossRef]

88. Li, Y.; Chen, Z.-Y.; Wang, W.; Baker, C.C.; Krug, R.M. The 3'-End-Processing Factor CPSF Is Required for the Splicing of Single-Intron Pre-MRNAs in Vivo. RNA 2001, 7, S1355838201010226. [CrossRef]

89. Chen, Z. Influenza A Virus NS1 Protein Targets Poly(A)-Binding Protein II of the Cellular 3'-End Processing Machinery. EMBO J. 2002, 18, 2273-2283. [CrossRef] 
90. Satterly, N.; Tsai, P.-L.; van Deursen, J.; Nussenzveig, D.R.; Wang, Y.; Faria, P.A.; Levay, A.; Levy, D.E.; Fontoura, B.M.A. Influenza Virus Targets the MRNA Export Machinery and the Nuclear Pore Complex. Proc. Natl. Acad. Sci. USA 2007, 104, 1853-1858. [CrossRef]

91. Zhang, K.; Xie, Y.; Muñoz-Moreno, R.; Wang, J.; Zhang, L.; Esparza, M.; García-Sastre, A.; Fontoura, B.M.A.; Ren, Y. Structural Basis for Influenza Virus NS1 Protein Block of MRNA Nuclear Export. Nat. Microbiol. 2019, 4, 1671-1679. [CrossRef] [PubMed]

92. Min, J.-Y.; Li, S.; Sen, G.C.; Krug, R.M. A Site on the Influenza A Virus NS1 Protein Mediates Both Inhibition of PKR Activation and Temporal Regulation of Viral RNA Synthesis. Virology 2007, 363, 236-243. [CrossRef] [PubMed]

93. Li, S.; Min, J.-Y.; Krug, R.M.; Sen, G.C. Binding of the Influenza A Virus NS1 Protein to PKR Mediates the Inhibition of Its Activation by Either PACT or Double-Stranded RNA. Virology 2006, 349, 13-21. [CrossRef] [PubMed]

94. Schierhorn, K.L.; Jolmes, F.; Bespalowa, J.; Saenger, S.; Peteranderl, C.; Dzieciolowski, J.; Mielke, M.; Budt, M.; Pleschka, S.; Herrmann, A.; et al. Influenza A Virus Virulence Depends on Two Amino Acids in the N-Terminal Domain of Its NS1 Protein To Facilitate Inhibition of the RNA-Dependent Protein Kinase PKR. J. Virol. 2017, 91, 1-18. [CrossRef] [PubMed]

95. Min, J.-Y.; Krug, R.M. The Primary Function of RNA Binding by the Influenza A Virus NS1 Protein in Infected Cells: Inhibiting the $2^{\prime}-5^{\prime}$ Oligo (A) Synthetase/RNase L Pathway. Proc. Natl. Acad. Sci. USA 2006, 103, 7100-7105. [CrossRef]

96. Ehrhardt, C.; Marjuki, H.; Wolff, T.; Nurnberg, B.; Planz, O.; Pleschka, S.; Ludwig, S. Bivalent Role of the Phosphatidylinositol-3-Kinase (PI3K) during Influenza Virus Infection and Host Cell Defence. Cell. Microbiol. 2006, 8, 1336-1348. [CrossRef]

97. Hale, B.G.; Kerry, P.S.; Jackson, D.; Precious, B.L.; Gray, A.; Killip, M.J.; Randall, R.E.; Russell, R.J. Structural Insights into Phosphoinositide 3-Kinase Activation by the Influenza A Virus NS1 Protein. Proc. Natl. Acad. Sci. USA 2010, 107, 1954-1959. [CrossRef]

98. Chen, G.; Liu, C.-H.; Zhou, L.; Krug, R.M. Cellular DDX21 RNA Helicase Inhibits Influenza A Virus Replication but Is Counteracted by the Viral NS1 Protein. Cell Host Microbe 2014, 15, 484-493. [CrossRef]

99. Carrasco, L.; de la Luna, S.; Ortin, J.; Aragon, T.; Nieto, A.; Novoa, I. Eukaryotic Translation Initiation Factor 4GI Is a Cellular Target for NS1 Protein, a Translational Activator of Influenza Virus. Mol. Cell. Biol. 2002, 20, 6259-6268.

100. Burgui, I.; Aragón, T.; Ortín, J.; Nieto, A. PABP1 and EIF4GI Associate with Influenza Virus NS1 Protein in Viral MRNA Translation Initiation Complexes. J. Gen. Virol. 2003, 84, 3263-3274. [CrossRef]

101. Falcon, A.M.; Fortes, P.; Marion, R.M.; Beloso, A.; Ortin, J. Interaction of Influenza Virus NS1 Protein and the Human Homologue of Staufen in Vivo and in Vitro. Nucleic Acids Res. 1999, 27, 2241-2247. [CrossRef] [PubMed]

102. Zhu, C.; Zheng, F.; Zhu, J.; Liu, M.; Liu, N.; Li, X.; Zhang, L.; Deng, Z.; Zhao, Q.; Liu, H. The Interaction between NOLC1 and IAV NS1 Protein Promotes Host Cell Apoptosis and Reduces Virus Replication. Oncotarget 2017, 8, 94519-94527. [CrossRef] [PubMed]

103. Shapira, S.D.; Gat-Viks, I.; Shum, B.O.V.; Dricot, A.; Marciela, M.; Liguo, W.; Gupta, P.B.; Hao, T.; Silver, S.J.; David, E.; et al. A Physical and Regulatory Map of Host-Influenza Interactions Reveals Pathways in H1N1 Infection. Cell 2009, 139, 1255-1267. [CrossRef] [PubMed]

104. De Chassey, B.; Aublin-Gex, A.; Ruggieri, A.; Meyniel-Schicklin, L.; Pradezynski, F.; Davoust, N.; Chantier, T.; Tafforeau, L.; Mangeot, P.-E.; Ciancia, C.; et al. The Interactomes of Influenza Virus NS1 and NS2 Proteins Identify New Host Factors and Provide Insights for ADAR1 Playing a Supportive Role in Virus Replication. PLoS Pathog. 2013, 9, e1003440. [CrossRef] [PubMed]

105. Raman, S.N.T.; Zhou, Y.; Raman, S.N.T.; Thulasi Raman, S.N.; Zhou, Y. Networks of Host Factors That Interact with NS1 Protein of Influenza A Virus. Front. Microbiol. 2016, 7, 654.

106. Kuo, R.L.; Li, Z.H.; Li, L.H.; Lee, K.M.; Tam, E.H.; Liu, H.M.; Liu, H.P.; Shih, S.R.; Wu, C.C. Interactome Analysis of the NS1 Protein Encoded by Influenza A H1N1 Virus Reveals a Positive Regulatory Role of Host Protein PRP19 in Viral Replication. J. Proteome Res. 2016, 15, 1639-1648. [CrossRef]

107. Ylösmäki, L.; Fagerlund, R.; Kuisma, I.; Julkunen, I.; Saksela, K. Nuclear Translocation of Crk Adaptor Proteins by the Influenza A Virus NS1 Protein. Viruses 2016, 8, 101. [CrossRef]

108. Marazzi, I.; Ho, J.S.Y.; Kim, J.; Manicassamy, B.; Dewell, S.; Albrecht, R.A.; Seibert, C.W.; Schaefer, U.; Jeffrey, K.L.; Prinjha, R.K.; et al. Suppression of the Antiviral Response by an Influenza Histone Mimic. Nature 2012, 483, 428-433. [CrossRef] 
109. Qin, S.; Liu, Y.; Tempel, W.; Eram, M.S.; Bian, C.; Liu, K.; Senisterra, G.; Crombet, L.; Vedadi, M.; Min, J. Structural Basis for Histone Mimicry and Hijacking of Host Proteins by Influenza Virus Protein NS1. Nat. Commun. 2014, 5, 3952. [CrossRef]

110. Han, X.; Li, Z.; Chen, H.; Wang, H.; Mei, L.; Wu, S.; Zhang, T.; Liu, B.; Lin, X. Influenza Virus A/Beijing/501/2009(H1N1) NS1 Interacts with $\beta$-Tubulin and Induces Disruption of the Microtubule Network and Apoptosis on A549 Cells. PLoS ONE 2012, 7, e48340. [CrossRef]

111. Mok, B.W.-Y.; Song, W.; Wang, P.; Tai, H.; Chen, Y.; Zheng, M.; Wen, X.; Lau, S.-Y.; Wu, W.L.; Matsumoto, K.; et al. The NS1 Protein of Influenza A Virus Interacts with Cellular Processing Bodies and Stress Granules through RNA-Associated Protein 55 (RAP55) during Virus Infection. J. Virol. 2012, 86, 12695-12707. [CrossRef] [PubMed]

112. Li, T.; Li, X.; Zhu, W.; Wang, H.; Mei, L.; Wu, S.; Lin, X.; Han, X. NF90 Is a Novel Influenza A Virus NS1-interacting Protein That Antagonizes the Inhibitory Role of NS1 on PKR Phosphorylation. FEBS Lett. 2016, 590, 2797-2810. [CrossRef] [PubMed]

113. Zhang, C.; Yang, Y.; Zhou, X.; Yang, Z.; Liu, X.; Cao, Z.; Song, H.; He, Y.; Huang, P. The NS1 Protein of Influenza a Virus Interacts with Heat Shock Protein Hsp90 in Human Alveolar Basal Epithelial Cells: Implication for Virus-Induced Apoptosis. Virol. J. 2011, 8, 181. [CrossRef] [PubMed]

114. Cheong, W.C.; Kang, H.R.; Yoon, H.; Kang, S.J.; Ting, J.P.Y.; Song, M.J. Influenza A Virus NS1 Protein Inhibits the NLRP3 Inflammasome. PLoS ONE 2015, 10, e0126456. [CrossRef]

115. Gao, S.; Song, L.; Li, J.; Zhang, Z.; Peng, H.; Jiang, W.; Wang, Q.; Kang, T.; Chen, S.; Huang, W. Influenza A Virus-Encoded NS1 Virulence Factor Protein Inhibits Innate Immune Response by Targeting IKK. Cell. Microbiol. 2012, 14, 1849-1866. [CrossRef]

116. Zhu, C.; Zheng, F.; Sun, T.; Duan, Y.; Cao, J.; Feng, H.; Shang, L.; Zhu, Y.; Liu, H. Interaction of Avian Influenza Virus NS1 Protein and Nucleolar and Coiled-Body Phosphoprotein 1. Virus Genes 2013, 46, 287-292. [CrossRef]

117. Dubois, J.; Traversier, A.; Julien, T.; Padey, B.; Lina, B.; Bourdon, J.; Marcel, V.; Bolvin, G.; Rosa-Calatrava, M.; Terrier, O. The Nonstructural NS1 Protein of Influenza Viruses Modulates TP53 Splicing through Host Factor CPSF4. J. Virol. 2019, 93, e02168-18. [CrossRef]

118. Yu, J.; Li, X.; Wang, Y.; Li, B.; Li, H.; Li, Y.; Zhou, W.; Zhang, C.; Wang, Y.; Rao, Z.; et al. PDlim2 Selectively Interacts with the PDZ Binding Motif of Highly Pathogenic Avian H5N1 Influenza A Virus NS1. PLoS ONE 2011, 6, e19511. [CrossRef]

119. Liu, H.; Golebiewski, L.; Dow, E.C.; Krug, R.M.; Javier, R.T.; Rice, A.P. The ESEV PDZ-Binding Motif of the Avian Influenza A Virus NS1 Protein Protects Infected Cells from Apoptosis by Directly Targeting Scribble. J. Virol. 2010, 84, 11164-11174. [CrossRef]

120. Kumar, M.; Liu, H.; Rice, A.P. Regulation of Interferon- $\beta$ by MAGI-1 and Its Interaction with Influenza A Virus NS1 Protein with ESEV PBM. PLoS ONE 2012, 7, e41251. [CrossRef]

121. Bavagnoli, L.; Dundon, W.G.; Garbelli, A.; Zecchin, B.; Milani, A.; Parakkal, G.; Baldanti, F.; Paolucci, S.; Volmer, R.; Tu, Y.; et al. The PDZ-Ligand and Src-Homology Type 3 Domains of Epidemic Avian Influenza Virus NS1 Protein Modulate Human Src Kinase Activity during Viral Infection. PLoS ONE 2011, 6, e27789. [CrossRef] [PubMed]

122. Richt, J.A.; García-Sastre, A.; Garcia-Sastre, A. Attenuated Influenza Virus Vaccines with Modified NS1 Proteins. Curr. Top. Microbiol. Immunol. 2009, 333, 177-195.

123. Wacheck, V.; Egorov, A.; Groiss, F.; Pfeiffer, A.; Fuereder, T.; Hoeflmayer, D.; Kundi, M.; Popow-Kraupp, T.; Redlberger-Fritz, M.; Mueller, C.A.; et al. A Novel Type of Influenza Vaccine: Safety and Immunogenicity of Replication-Deficient Influenza Virus Created by Deletion of the Interferon Antagonist NS1. J. Infect. Dis. 2010, 201, 354-362. [CrossRef] [PubMed]

124. Morokutti, A.; Muster, T.; Ferko, B. Intranasal Vaccination with a Replication-Deficient Influenza Virus Induces Heterosubtypic Neutralising Mucosal IgA Antibodies in Humans. Vaccine 2014, 32, 1897-1900. [CrossRef] [PubMed]

125. Nicolodi, C.; Groiss, F.; Kiselev, O.; Wolschek, M.; Seipelt, J.; Muster, T. Safety and Immunogenicity of a Replication-Deficient H5N1 Influenza Virus Vaccine Lacking NS1. Vaccine 2019, 37, 3722-3729. [CrossRef]

126. Mossler, C.; Groiss, F.; Wolzt, M.; Wolschek, M.; Seipelt, J.; Muster, T. Phase I/II Trial of a Replication-Deficient Trivalent Influenza Virus Vaccine Lacking NS1. Vaccine 2013, 31, 6194-6200. [CrossRef]

127. Eyer, L.; Hruska, K. Antiviral Agents Targeting the Influenza Virus: A Review and Publication Analysis. Vet. Med. 2013, 58, 113-185. [CrossRef] 
128. Ortigoza, M.B.; Dibben, O.; Maamary, J.; Martinez-Gil, L.; Leyva-Grado, V.H.; Abreu, P.; Ayllon, J.; Palese, P.; Shaw, M.L. A Novel Small Molecule Inhibitor of Influenza A Viruses That Targets Polymerase Function and Indirectly Induces Interferon. PLoS Pathog. 2012, 8, e1002668. [CrossRef]

129. Wu, Y.; Zhang, G.; Li, Y.; Jin, Y.; Dale, R.; Sun, L.-Q.; Wang, M. Inhibition of Highly Pathogenic Avian H5N1 Influenza Virus Replication by RNA Oligonucleotides Targeting NS1 Gene. Biochem. Biophys. Res. Commun. 2008, 365, 369-374. [CrossRef]

130. Rajput, R.; Khanna, M.; Kumar, P.; Kumar, B.; Sharma, S.; Gupta, N.; Saxena, L. Small Interfering RNA Targeting the Nonstructural Gene 1 Transcript Inhibits Influenza A Virus Replication in Experimental Mice. Nucleic Acid Ther. 2012, 22, 414-422. [CrossRef]

131. Wen, X.; Sun, J.; Wang, X.; Bao, H.; Zhao, Y.; Zeng, X.; Xu, X.; Ma, Y.; Gu, L.; Chen, H. Identification of a Novel Linear Epitope on the NS1 Protein of Avian Influenza Virus. BMC Microbiol. 2015, 15, 168. [CrossRef] [PubMed]

132. He, J.-L.; Hsieh, M.-S.; Chiu, Y.-C.; Juang, R.-H.; Wang, C.-H. Preparation of Monoclonal Antibodies against Poor Immunogenic Avian Influenza Virus Proteins. J. Immunol. Methods 2013, 387, 43-50. [CrossRef] [PubMed]

133. Rai, M.; Bhatia, S.; Malik, Y.P.S.; Dubey, S.C. Production and Characterization of Monoclonal Antibodies Against NS1 Protein of H5N1 Avian Influenza Virus. Hybridoma 2010, 29, 183-186. [CrossRef] [PubMed]

134. Berman, H.M.; Westbrook, J.; Feng, Z.; Gilliland, G.; Bhat, T.N.; Weissig, H.; Shindyalov, I.N.; Bourne, P.E. The Protein Data Bank. Nucleic Acids Res. 2000, 28, 235-242. [CrossRef] [PubMed]

135. Shen, Z.; Lou, K.; Wang, W. New Small-Molecule Drug Design Strategies for Fi Ghting Resistant in Fl Uenza A. Acta Pharm. Sin. B 2015, 5, 419-430. [CrossRef]

136. Basu, D.; Walkiewicz, M.P.; Frieman, M.; Baric, R.S.; Auble, D.T.; Engel, D.A. Novel Influenza Virus NS1 Antagonists Block Replication and Restore Innate Immune Function. J. Virol. 2009, 83, 1881-1891. [CrossRef]

137. Beyleveld, G.; White, K.M.; Ayllon, J.; Shaw, M.L. New-Generation Screening Assays for the Detection of Anti-Influenza Compounds Targeting Viral and Host Functions. Antivir. Res. 2013, 100, 120-132. [CrossRef]

138. Walkiewicz, M.P.; Basu, D.; Jablonski, J.J.; Geysen, H.M.; Engel, D.A. Novel Inhibitor of Influenza Non-Structural Protein 1 Blocks Multi-Cycle Replication in an RNase L-Dependent Manner. J. Gen. Virol. 2011, 92, 60-70. [CrossRef]

139. Jablonski, J.J.; Basu, D.; Engel, D.A.; Geysen, H.M. Design, Synthesis, and Evaluation of Novel Small Molecule Inhibitors of the Influenza Virus Protein NS1. Bioorg. Med. Chem. 2012, 20, 487-497. [CrossRef]

140. Kleinpeter, A.B.; Jureka, A.S.; Falahat, S.M.; Green, T.J.; Petit, C.M. Structural Analyses Reveal the Mechanism of Inhibition of Influenza Virus NS1 by Two Antiviral Compounds. J. Biol. Chem. 2018, 293, 14659-14668. [CrossRef]

141. Patnaik, S.; Basu, D.; Dehdashti, S.; Zheng, W.; Ferrer, M.; Southall, N.; Taylor, M.; Engel, D.A.; Marugan, J.J. Discovery of Small Molecule Influenza Virus NS1 Antagonist; U.S. National Library of Medicine: Bethesda, MD, USA, 2012.

142. Kong, J.; Shen, J.; Huang, Y.; Ruan, R.; Xiang, B.; Zheng, X.; Cheng, K.; Wang, W. Development of a Yeast Two-Hybrid Screen for Selection of A/H1N1 Influenza NS1 Non-Structural Protein and Human CPSF30 Protein Interaction Inhibitors. Acta Pharm. Sin. 2010, 45, 388-394.

143. Mata, M.A.; Satterly, N.; Versteeg, G.A.; Frantz, D.; Wei, S.; Williams, N.; Schmolke, M.; Peña-Llopis, S.; Brugarolas, J.; Forst, C.V.; et al. Chemical Inhibition of RNA Viruses Reveals REDD1 as a Host Defense Factor. Nat. Chem. Biol. 2011, 7, 712-719. [CrossRef] [PubMed]

144. Cho, E.J.; Xia, S.; Ma, L.-C.; Robertus, J.; Krug, R.M.; Anslyn, E.V.; Montelione, G.T.; Ellington, A.D. Identification of Influenza Virus Inhibitors Targeting NS1A Utilizing Fluorescence Polarization-Based High-Throughput Assay. J. Biomol. Screen. 2012, 17, 448-459. [CrossRef] [PubMed]

145. You, L.; Cho, E.J.; Leavitt, J.; Ma, L.-C.; Montelione, G.T.; Anslyn, E.V.; Krug, R.M.; Ellington, A.; Robertus, J.D. Synthesis and Evaluation of Quinoxaline Derivatives as Potential Influenza NS1A Protein Inhibitors. Bioorg. Med. Chem. Lett. 2011, 21, 3007-3011. [CrossRef]

146. Maroto, M.; Fernandez, Y.; Ortin, J.; Pelaez, F.; Cabello, M.A. Development of an HTS Assay for the Search of Anti-Influenza Agents Targeting the Interaction of Viral RNA with the NS1 Protein. J. Biomol. Screen. 2008, 13, 581-590. [CrossRef]

147. Kuss-Duerkop, S.K.; Wang, J.; Mena, I.; White, K.; Metreveli, G.; Sakthivel, R.; Mata, M.A.; Muñoz-Moreno, R.; Chen, X.; Krammer, F.; et al. Influenza Virus Differentially Activates MTORC1 and MTORC2 Signaling to Maximize Late Stage Replication. PLoS Pathog. 2017, 13, e1006635. [CrossRef]

148. Martínez-Gil, L.; Ayllon, J.; Ortigoza, M.B.; García-Sastre, A.; Shaw, M.L.; Palese, P. Identification of Small Molecules with Type I Interferon Inducing Properties by High-Throughput Screening. PLoS ONE 2012, 7, e49049. [CrossRef] 
149. Shimberg, G.D.; Michalek, J.L.; Oluyadi, A.A.; Rodrigues, A.V.; Zucconi, B.E.; Neu, H.M.; Ghosh, S.; Sureschandra, K.; Wilson, G.M.; Stemmler, T.L.; et al. Cleavage and Polyadenylation Specificity Factor 30: An RNA-Binding Zinc-Finger Protein with an Unexpected 2Fe-2S Cluster. Proc. Natl. Acad. Sci. USA 2016, 113, 4700-4705. [CrossRef]

150. Ai, H.; Zhang, L.; Chang, A.K.; Wei, H.; Che, Y.; Liu, H. Virtual Screening of Potential Inhibitors from TCM for the CPSF30 Binding Site on the NS1A Protein of Influenza A Virus. J. Mol. Model. 2014, 20, 2142. [CrossRef]

151. Morris, G.M.; Huey, R.; Lindstrom, W.; Sanner, M.F.; Belew, R.K.; Goodsell, D.S.; Olson, A.J. AutoDock4 and AutoDockTools4: Automated Docking with Selective Receptor Flexibility. J. Comput. Chem. 2009, 30, 2785-2791. [CrossRef]

152. Ai, H.; Zheng, F.; Zhu, C.; Sun, T.; Zhang, L.; Liu, X.; Li, X.; Zhu, G.; Liu, H. Discovery of Novel Influenza Inhibitors Targeting the Interaction of DsRNA with the NS1 Protein by Structure-Based Virtual Screening. Int. J. Bioinform. Res. Appl. 2010, 6, 449. [CrossRef] [PubMed]

153. Liang, S.; Li, L.; Hsu, W.-L.; Pilcher, M.N.; Uversky, V.; Zhou, Y.; Dunker, A.K.; Meroueh, S.O. Exploring the Molecular Design of Protein Interaction Sites with Molecular Dynamics Simulations and Free Energy Calculations. Biochemistry 2009, 48, 399-414. [CrossRef] [PubMed]

154. Genheden, S.; Ryde, U. The MM/PBSA and MM/GBSA Methods to Estimate Ligand-Binding Affinities. Expert Opin. Drug Discov. 2015, 10, 449-461. [CrossRef] [PubMed]

155. Tieleman, D.P.; Berendsen, H.J.C. Molecular Dynamics Simulations of a Fully Hydrated Dipalmitoylphosphatidylcholine Bilayer with Different Macroscopic Boundary Conditions and Parameters. J. Chem. Phys. 1996, 105, 4871-4880. [CrossRef]

156. Hutchinson, E.C.; Charles, P.D.; Hester, S.S.; Thomas, B.; Trudgian, D.; Martínez-Alonso, M.; Fodor, E. Conserved and Host-Specific Features of Influenza Virion Architecture. Nat. Commun. 2014, 5, 4816. [CrossRef]

157. Phillips, J.C.; Braun, R.; Wang, W.; Gumbart, J.; Tajkhorshid, E.; Villa, E.; Chipot, C.; Skeel, R.D.; Kalé, L.; Schulten, K. Scalable Molecular Dynamics with NAMD. J. Comput. Chem. 2005, 26, 1781-1802. [CrossRef]

158. Iwasaki, A.; Pillai, P.S. Innate Immunity to Influenza Virus Infection. Nat. Rev. Immunol. 2014, 14, 315-328. [CrossRef]

159. Barnwal, B.; Mok, C.-K.; Wu, J.; Diwakar, M.K.; Gupta, G.; Zeng, Q.; Chow, V.T.K.; Song, J.; Yuan, Y.A.; Tan, Y.-J. A Monoclonal Antibody Binds to Threonine 49 in the Non-Structural 1 Protein of Influenza A Virus and Interferes with Its Ability to Modulate Viral Replication. Antivir. Res. 2015, 116, 55-61. [CrossRef]

160. Zhang, H. Tissue and Host Tropism of Influenza Viruses: Importance of Quantitative Analysis. Sci. China Ser. C Life Sci. 2009, 52, 1101-1110. [CrossRef]

161. Eng, C.L.; Tong, J.; Tan, T. Predicting Host Tropism of Influenza A Virus Proteins Using Random Forest. BMC Med. Genom. 2014, 7, S1. [CrossRef]

162. Pavlin, B.I.; Schloegel, L.M.; Daszak, P. Risk of Importing Zoonotic Diseases through Wildlife Trade, United States. Emerg. Infect. Dis. 2009, 15, 1721-1726. [CrossRef] [PubMed]

163. Squires, R.B.; Noronha, J.; Hunt, V.; García-Sastre, A.; Macken, C.; Baumgarth, N.; Suarez, D.; Pickett, B.E.; Zhang, Y.; Larsen, C.N.; et al. Influenza Research Database: An Integrated Bioinformatics Resource for Influenza Research and Surveillance. Influenza Other Respir. Viruses 2012, 6, 404-416. [CrossRef] [PubMed]

164. Rajao, D.S.; Anderson, T.K.; Gauger, P.C.; Vincent, A.L. Evolution and Ecology of Influenza A Viruses. In Current Topics in Microbiology and Immunology Influenza Pathogenesis and Control-Volume I; Springer: Cham, Switzerland, 2014; Volume 385, pp. 307-321.

165. Kargarfard, F.; Sami, A.; Mohammadi-Dehcheshmeh, M.; Ebrahimie, E. Novel Approach for Identification of Influenza Virus Host Range and Zoonotic Transmissible Sequences by Determination of Host-Related Associative Positions in Viral Genome Segments. BMC Genom. 2016, 17, 925. [CrossRef] [PubMed]

166. Yen, H.-L. Current and Novel Antiviral Strategies for Influenza Infection. Curr. Opin. Virol. 2016, 18, $126-134$. [CrossRef] [PubMed]

167. Eng, C.L.P.; Tong, J.C.; Tan, T.W. Distinct Host Tropism Protein Signatures to Identify Possible Zoonotic Influenza A Viruses. PLoS ONE 2016, 11, e0150173. [CrossRef]

(C) 2020 by the authors. Licensee MDPI, Basel, Switzerland. This article is an open access article distributed under the terms and conditions of the Creative Commons Attribution (CC BY) license (http://creativecommons.org/licenses/by/4.0/). 